\author{
REVIEW OF EUROPEAN AND COMPARATIVE LAW \\ VOLUME XXXIX \\ YEAR 2019
}

\title{
EU-JAPAN AGREEMENTS: CONTENT, CONTEXT AND IMPLICATIONS
}

\author{
Andżelika Kǘnar*, Jerzy Menkes**
}

\begin{abstract}
The article analyses the agreements concluded by the EU with Japan: Economic Partnership Agreement, Strategic Partnership Agreement and the negotiated agreement: Investment Protection Agreement. EPA liberalizes trade in goods and services. By setting the legal framework for a strategic partnership, SPA facilitates cooperation against common challenges. IPA will regulate standards for investment protection and disputes resolution.

The analysis consists: - the content of the Agreements; - socio-economic and political potential of the parties; - EU's legal powers to negotiate and conclude agreements, and its competence, whether exclusive or shared, to enter into these Agreements; - the importance of Agreements for their parties and for other international actors as well as for regional, trans-regional and global relations.

The thesis of the study is the statement that in a world where instability is increasing and security is reduced, the parties are fulfilling their, as real great powers, obligation to bear special responsibility for the implementation of the values represented. The Agreements confirm the community of values on which they are embedded and create conditions for strengthening these values.

The study consists of five parts. First we analyse the subject matter of the Agreements, then their actors, and the reasons of concluding them and why. In part IV we explain the importance of the Agreements for the contracting parties and for

Andżelika Kuźnar, SGH Professor, Institute of International Economics, Collegium of World Economy, Warsaw School of Economics, e-mail: andzelika.kuznar@ sgh.waw.pl, ORCID 0000-0002-7042-4592;

** Jerzy Menkes, Professor, Department of European Integration and Law, Collegium of World Economy, Warsaw School of Economics, e-mail:jerzy.menkes@sgh.waw.pl, ORCID 0000-0002-7744-8167
\end{abstract}


the international community, and in part V we concentrate on the Agreements as seen from the external perspective.

The conclusions state that the Agreements institutionalise security community where the security and defence policy component is still relatively weak, but is also being developed. The agreements making closer political and economic ties between the UE and Japan open the way to creation of the EU's security community with "democratic diamonds" in the Asia-Pacific region.

Key words: EU, Japan, EPA, SPA, IPA

\section{INTRODUCTION}

In this document we analyze the following agreements between the EU and Japan which were signed: Economic Partnership Agreement (EPA), Strategic Partnership Agreement (SPA) and one that is negotiated: Investment Protection Agreement (IPA). EPA liberalizes trade in goods and services. By setting the legal framework for a strategic partnership, SPA facilitates cooperation against common challenges. IPA will regulate standards for investment protection and disputes resolution.

The subject scope of the analysis consists of: - the content of the EU-Japan Agreements; - socio-economic and political potential of the Parties; - EU's legal powers to negotiate and conclude agreements with Japan, and its competence, whether exclusive or shared, to enter into these Agreements; - the importance of Agreements for their Parties and for other international actors as well as for regional, trans-regional and global relations.

The thesis of the study is the statement that in a world where instability is increasing and security is reduced, the Parties are fulfilling their, as real great powers, obligation to bear special responsibility for the implementation of the values represented. We claim, that the Agreements confirm the community of values on which they are embedded and create conditions for strengthening these values.

It is a comprehensive study: multidisciplinary (legal, economic) and interdisciplinary (law \& economy). The economic study uses quantitative and qualitative analysis methods, while the legal study uses the New Haven Law School's approach and the Rational choice approach is used in the in- 
terdisciplinary study ${ }^{1}$. When deciding to create Agreements, the Parties were guided by the assessment of their overall effect, which we also assess.

The study consists of five parts. First we analyse the subject matter of the Agreements (part I: What?), then their actors (part II: Who?), and the reasons of concluding them (part III: How (modus operandi) and why (like that)?). In part IV (Weight of the Agreements) we explain the importance of the Agreements for the contracting Parties and for the international community, and finally in part $V$ (Agreements in the light of of pluri- and multilateral relations) we concentrate on the Agreements as seen from the external perspective.

\section{WHAT?}

On February 1, 2019 EPA entered into force - the largest free trade zone in the world ${ }^{2}$ started operation on that day. Also on that day, as a result of provisional application of SPA, the largest area of free and safe personal data flows was created in the world ${ }^{3}$. The Parties, with the package of newly created agreements, generate a legal framework of "enhanced political and sectoral cooperation and joint actions on issues of common interest, including on regional and global challenges"4.

Both EPA and SPA are an expression of the Parties' support - for the institutionalization of plurilateral cooperation, and against interna-

1 See: Robert Keohane, "Rational Choice and International Law" Journal of Legal Studies 1 (2002), 307-319, December 1, 2019 https://papers.ssrn.com/sol3/papers. cfm?abstract_id $=355020$.

2 Total trade between Japan and the EU is about 175 billion euro. In $2016 \mathrm{EU}$ exports of goods and services to Japan reached 89 billion euro. Japanese exports to EU valued at 85 billion euro. The expected outcome of EPA is increase of EU exports to Japan by 14 billion euro, and from Japan to EU by 22 billion euro. See: The Economic Impact of the EU - Japan Economic Partnership Agreement (EPA). An analysis prepared by the European Commission's Directorate-General for Trade, European Commission 2018. Retrieved from: http:// trade.ec.europa.eu/doclib/docs/2018/july/tradoc_157116.pdf (access date: 15.05.2019).

3 EPA and SPA were signed on July 17, 2018.

4 EU-Japan trade agreement enters into force, European Commission, 2019, January 31. Retrieved from: http://europa.eu/rapid/press-release_IP-19-785_en.htm (access date: 15.05 .2019$)$. 
tional relations in the form of single and one-dimensional transactions and the pursuit of immediate profits; - for free and fair trade, and against protectionism; - for the commitment and will to implement the values and principles ${ }^{5}$ common to both societies in all spheres - alongside the economy - security, sustainable development, climate protection, consumer protection, labour standards, etc., etc.

The agreements have created an economic and socio-political framework for EU-Japan relations. They have different legal status: $-\mathrm{EPA}^{6}$ is in force; $-\mathrm{SPA}^{7}$ is provisionally applied and awaits ratification ${ }^{8}$; - IPA is being negotiated' . EPA - for the most part - has liberalized trade in goods and services. SPA sets the legal framework for strategic partnership, confirms the community of values and facilitates cooperation against common challenges (Article 1). IPA will regulate legal standards for investment protection and (above all) dispute resolution (in form of ISDS, but also SSDS). EPA and IPA are „new generation” EU agreements ${ }^{10}$.

5 These include democracy, the rule of law, human rights, good governance and market-based economy.

6 Annex to the Proposal for a Council Decision on the conclusion of the Economic Partnership Agreement between the European Union and Japan, European Commission, 2018, April 18. Retrieved from: https://eur-lex.europa.eu/legal-content/EN/TXT/?uri=CELEX:52018PC0192\#document2 (access date:19.02.2019).

7 Council Decision (EU) 2018/1197 of 26 June 2018 on the signing, on behalf of the European Union, and provisional application of the Strategic Partnership Agreement between the European Union and its Member States, of the one part, and Japan, of the other part, OJ L 216/1, Retrieved from: https://eur-lex.europa.eu/eli/dec/2018/1197/ oj (access date: 15.05.2019).

8 The SPA entered into force on February 1, 2019. The ratification process has been completed within the envisaged deadline. The first Joint Committee under the Japan-EU Strategic Partnership Agreement was held on March 25, 2019 in Tokyo. The first Joint Committee of the Japan-EU Strategic Partnership Agreement (SPA), MOFA, 25.03.2019. Retrieved from: https://www.mofa.go.jp/press/release/press4e_002392.html (access date: 10.04.2019).

9 The lack of declarations on the state of progress on IPA indicates only that the Parties keep it in a tightly closed room, in which, however, a consensus was created. The ratification of SPA and IPA will also require a positive decision from the parliaments of the Member States.

10 That is a comprehensive trade agreement regulating not only trade in goods but also services and providing for not only elimination of customs duties but gradual abolition of all restrictions in international trade (Consolidated versions of the Treaty on Europe- 
EPA is a bilateral agreement connecting the EU with Japan. The EU has exclusive competence in areas covered by the agreement, therefore EPA entered into force on the basis decision of the Council and consent of the European Parliament ${ }^{11}$. It results from the decision to include in the agreement only the domains falling within the exclusive competence of the EU and not to include, by contrario, the issues going beyond this scope, consisting of provisions regarding the broadly understood investment issues. These issues will form the IPA, which will include, inter alia: regulation of investments other than direct investments, investment protection, material and procedural issues of investor-state dispute resolution. EU, remembering difficulties and controversies accompanying the conclusion and ratification of CETA, decided at all costs to avoid the conclusion of one large mixed agreement with Japan. The Court of Justice in its Opinion 2/15 of 16 May 2017 on the European Union's Free Trade Agreement with Singapore ${ }^{12}$ helped to stratify provisions falling under the exclusive competence of the EU and shared competence between the EU and the Member States. The Court of Justice has clearly indicated that agreements serving the implementation of the disposition of Article 216 of the Treaty on the Functioning of the European Union belong to the matter covered by shared competences, while the matter of Article 207 of the Treaty belongs to the sphere of exclusive competence. In this situation, the Commission, as part of the division of EU treaty relations with Japan into economic and political, has separated economic relations into trade and investment ones. This procedure has made - as it seems - easier to create regulations, at the same time giving away the threat of a political dispute and difficulties

an Union and the Treaty on the Functioning of the European Union, OJ C 202/1, Volume 59, 7 June 2016, Retrieved from: https://eur-lex.europa.eu/legal-content/EN/TXT/ HTML/?uri=OJ:C:2016:202:FULL\&from=EN (access date: 1.04.2019), title: Common commercial policy, 139) within the Strategy „Trade for All” (Trade for All - New EU Trade and Investment Strategy, European Commission, 04.04.2016. Retrieved from: http:// ec.europa.eu/trade/policy/in-focus/new-trade-strategy/index_en.htm (1.04.2019).

11 It was not subject to ratification by EU Member States.

12 Opinion of the Court (Full Court) of 16 May 2017 - European Commission, OJ C 363, 3.11.2015. Retrieved from: http://curia.europa.eu/juris/document/document. jsf?docid $=193125 \&$ text $=\&$ dir $=\&$ doclang $=E N \&$ part $=1$ \&occ $=$ first \&mode=DOC\&pageIndex $=0 \&$ cid $=4517259$ (access date: 3.04 .2018 ). 
with ratification of the agreement regulating merits of investment matters (de facto ISDS matters.)

The investment issues have been partially regulated by EPA, which does not cover investment protection standards and investment protection dispute resolution. They are going to be regulated in IPA, which will regulate the investment issues comprehensively, referring and repeating (partially) the relevant EPA standards and it will comprehensively regulate material, as well as procedural and legal issues in the settlement of investment disputes ${ }^{13}$. The separation of investment protection from EPA, in particular the settlement of investment disputes, makes it a non-standard agreement (this separation is artificial). At the same time, the Parties indicated unequivocally that they treat the domain of investment as inseparable from economic relations, as evidenced by its combined treatment with the remaining regulated matters in the Preamble of the Agreement. Normative statements of the Preamble indicate the fact that the matter of protecting the investment is covered by the pactum de contrahendo. This proves the tactical nature of the separation of this domain, used for internal use of the EU - this has facilitated the ratification. Separation is therefore a defence against populism and demagogy, derived from experience. However, this modus operandi tactic - creation a policy of fait accompli, raises doubts as to whether it does not lead to a circumvention of law-democracy, which in the medium and long term may endanger existing civil societies (in mature democracies ${ }^{14}$ ) or not favour the development of civil societies (in immature democracies ${ }^{15}$ ).

EPA and IPA are embedded on a foundation of shared values and principles. There is a two-way action between them and SPA. A set of agreements is intended to implement a strategic partnership ${ }^{16}$ between the Parties.

13 First of all, the most controversial investor-state disputes but also state-state disputes.

14 So called „Old Europe” (old EU Members states).

15 New Europe, the countries that acceded to the EU after the systemic transformation (former communist countries). Terms used by Donald Rumsfeld (US Secretary of State) in January 2003; Secretary Rumsfeld Briefs at the Foreign Press Center. Retrieved from: https://web.archive.org/web/20130606002456/http://video.msnbc.msn.com/msnbc/4017033 (access date: 17.07.2019).

16 See: Preamble of SPA. 
EPA is solely a trade agreement. It belongs to one of the three subsets that make up a set of EU trade agreements, which $\operatorname{are}^{17}$ : - customs unions ${ }^{18}$; association agreements ${ }^{19}$, stabilization agreements ${ }^{20}$, (deep and comprehensive) free trade agreements ${ }^{21}$, economic partnership agreements ${ }^{22}$; - partnership and cooperation agreements ${ }^{23}$. EPA will promote trade through the elimination of tariffs and the reduction of non-tariff barriers, including the regulatory cooperation or harmonisation of law between the Parties. Through its conclusion, the Parties establish a free trade area.

However, EPA's importance for the overall relationship between the Parties and the global society goes beyond the trade dimension.

On the one hand, EPA will affect the world economy and society, on the other hand it is a response to challenges and opportunities, a proof of awareness of the effects of globalization by the Parties and deepening economic integration (Preamble). This proves the acceptance of the two-way action between the indicated phenomena and processes.

The Parties to the Agreement strongly emphasize the values that unite them, making at the same time - which is politically interesting - a choice of standards that set this system, namely, recalling the values expressed in the United Nations Charter and the Universal Declaration of Human Rights (and not in the human rights pacts). The proof of the community of values of the Parties is also the announcement of cooperation at the UN forum in the creation of new regulations in the field of safety and environmental protection (related, inter alia, to automotive, Annex 2-C).

17 The list of treaties and their texts: Treaties Office Database. Retrieved from: http:// ec.europa.eu/world/agreements/searchByType.do?id=1 (access date: 10.04.2019).

18 They abolish duties in trade between the Parties and establish a common customs tariff for third party(ies); a classic example is the agreements with San Marino and Andorra.

19 For example with Georgia, Israel, Ukraine.

20 In practice, they also establish associations; e.g. with Albania, Bosnia and Herzegovina, Kosovo.

${ }^{21}$ For example, with South Africa, Mozambique, Namibia, negotiated with Morocco or Tunisia.

22 Their effect is the reduction or elimination of duties in bilateral exchange; e.g. agreements with Fiji, Papua New Guinea.

23 They provide a framework for bilateral economic relations, do not regulate the level of tariffs; e.g. with Azerbaijan, Georgia. 
This cooperation, however, extended to all international organisations and forums, is also covered by Article 1.B.SPA.

The effect of implementation of EPA is the ongoing liberalization of trade in goods and services. The Agreement is within the standards set for this type of agreements. The standard also includes the provision in Articles 5.2 to 5.9 for safeguard measures and the general rule to protect Parties by means of collective value legal standards (e.g. in relation to services, Article 8.1.2 "For the purposes of this Chapter, the Parties reaffirm their right to introduce in their territory regulatory measures necessary to achieve legitimate policy objectives, such as the protection of public health, safety, the environment or public morals, social protection and consumer protection, or the promotion and protection of cultural diversity"). The outcome of negotiations is that both Parties agreed to provide almost free bilateral access to their markets. Japan will eventually (after 15 years of entry of the Agreement into force) fully liberalise $97 \%$ of its tariff lines (86\% immediately at the entry into force) and $99 \%$ of imports, while the EU will liberalise $99 \%$ of its tariff lines (96\% at the entry into force) and 100\% of imports. On the $3 \%$ of tariff lines not fully liberalised, Japan has given significant concessions in terms of tariff rate quotas or tariff reductions.

Apart from elimination of tariffs, the non-tariff measures in relation to manufacturing and agricultural goods are reduced or eliminated, and the common rules for determining the origin of goods, technical barriers to trade, sanitary and phytosanitary measures are being introduced.

Particularly important, from the point of view of implementation of EPA, are extensive, detailed dispositions regulating the determination of the "rules of origin" ${ }^{24}$. Issues relating to this matter - disputes in case of the absence of regulation, may in fact prevent any agreement regulating trade in goods or introduce significant non-tariff restrictions, or be a source of continuing controversy. The regulations of Chapter 3 in connection with Annex 3-B of the EPA can be considered adequate to the current and potential needs, and the application regime set out in Article 3.6 (Tolerances) is a rational regime. At the same time, the EPA protects against abuse of derivative rights by refusing to recognise the origin

24 Packages of private persons or personal luggage with regard to goods not imported for commercial purposes shall be exempted from the rules of origin requirements. 
in the event of insufficient processing or working (Article 3.4). It should not be difficult to apply the regulation in practice, as the procedures (Section B) do not contain any elements hindering the exercise of rights by operators. The Parties have decided to cooperate in the fight against fraud, which will also include administrative cooperation and assistance.

An important element of the institutionalisation of the regulation is the establishment of the Committee on Rules of Origin and Customs-Related Matters, which will be responsible for the implementation and functioning of the relevant EPA regulations (Article 3.28.1).

EPA Parties confirmed both the fact that technical barriers to trade (TBT), in many cases, only serve to protect the market, and do not serve the declared purposes and the will to eliminate the existing TBT and not to introduce the new ones. This is illustrated, with regard to motor vehicles and their components, by the provisions of Article $11.1^{25}$ and Article 12.126 Annex 2-C. The Parties also decided to establish institutional and procedural safeguards against breach of agreement in the future (Article 13). The above regulations should not be treated as a special regime. They indicate the objectives and intentions of the Parties and the way of preventing and resolving disputes and avoiding conflicts.

In the case of liberalization in trade in services, the scope of the agreement is very broad. An important element of EPA - from the point of view of public debate - is the way the "public services" were regulated. During the preparation for the conclusion of $\mathrm{CETA}^{27}$ and TTIP, the representatives of extreme positions in public opinion stimulated fears of the alleged

25 „The Parties shall refrain from amending existing domestic technical regulations in a manner that renders them more trade-restrictive than necessary to fulfil a legitimate objective for the importation and the putting into service on their domestic market of products for which type approvals have been granted pursuant to UN Regulations".

26 „The Parties shall refrain from introducing any new domestic technical regulations or conformity assessment procedures which have the effect of preventing or increasing the burden for the importation and the putting into service on their domestic market of products for which type approvals have been granted under UN Regulations applied by both Parties, for the areas covered by those UN Regulations unless such domestic technical regulations or conformity assessment procedures are explicitly provided for by those UN Regulations".

27 More on CETA analysed from the perspective of the "agreement [that] represents the archetype for new trade regimes" in: Kurt Hubner, Tugce Balik, Anne-Sophie Deman, "CETA: the Making of the Comprehensive Economic and Trade Agreement Between Can- 
forced privatization of public services as a result of concluding agreements. Apart from the rationality of fears (their awakening was an element of the political game of people and Parties building social support for fears), they threatened the Agreements. Therefore, it is important that EPA includes a negative regulation explicitly stating what the agreement does not require ${ }^{28}$. Of course, the source of obligations is the Agreement, so the legislative logic, which regulates what is not regulated, is questionable, but the Agreement will function not only between the Parties and in real life, but also in the political game, so the applied method of regulation makes it easier to be bound by the Agreement.

EPA significantly liberalizes movement of people, which is important from the point of view of the EU. Lifting existing restrictions will allow European entities (both natural and legal persons) to operate directly on the Japanese market. The relevant regulations are contained in Chapter 8, Section D (and Annexes III, IV, 8-C). Already in the "general provisions" it is made clear that the provisions in question reflect the strengthening of trade relations and the desire to remove obstacles to the entry and temporary stay of natural persons. The regulations of Section D - according to Article 8.20.2 - are applicable to "measures by a Party affecting the entry into that Party by natural persons of the other Party, who are business visitors for establishment purposes, intra-corporate transferees, investors, contractual service suppliers, independent professionals and short-term business visitors, and to measures affecting their business activities during their temporary stay in the former Party".

SPA embeds cooperation of Parties in the context of the paradigm they represent. A broad catalogue of values and views constituting this

ada and the EU', Notes de l'Ifri, April (2016), 7-34, December 1 https://www.ifri.org/ sites/default/files/atoms/files/notes_ifri_ceta.pdf.

28 "On the question of public services, the EU-Japan Free Trade Agreement, like all other EU free trade agreement, maintains the right of Member States' authorities to keep public services public and it will not require governments to privatize or deregulate any public service at national or local level. Member States' authorities retain the right to bring in to the public sector any privately provided services. Europeans will continue to decide for themselves how they want, for example, their healthcare, education and water delivered"; EU-Japan - The Agreement in Principle, 6 July 2017. Retrieved from: http://trade. ec.europa.eu/doclib/docs/2017/july/tradoc_155693.doc.pdf (access date: 15.04.2018). 
paradigm has been articulated in the Preamble. The statements contained in the Preamble have a clear normative content which determines the binding force of Preamble. The catalogue of challenges indicated in the Preamble is controversial ${ }^{29}$, despite the declaration that it is not exhaustive. "Proliferation of weapons of mass destruction, terrorism, climate change, poverty and infectious diseases, and threats of common interest in the maritime domain, cyberspace and outer space; ... most serious crimes ..." were indicated, while for example aggression and annexation of territories were not.

On the one hand, SPA cannot be underestimated, on the other hand, its dogmatic and functional analysis speaks in favour of recognising that it is more of a dialogue with US politics - Trump's statements - than a closed, comprehensive declaration. The Parties use the SPA as a tool to complement the policy of the West and to maintain its components negated by the United States. What is new - but known from the EPA is the appreciation of the Universal Declaration of Human Rights at the expense of concealed pacts. The reasoning of SPA leads to questioning the legal quality of the Agreement when the Parties once (classically) indicate that disputes should be settled in accordance with international law (Article 3), and earlier (Article 1.1(c)) complemented this basis - revolutionary - with the necessity of the settlement of disputes in conformity with the principles of justice - giving it additional priority of application. The SPA also contains numerous regulations concerning economic relations. Articles 13 to 31 are common to the EPA and IPA regulations. Articles 32 and 33 regulate judicial cooperation in the domain of home affairs (combating corruption and organised crime). Generally, the SPA confirms and deepens the conviction that the separation of EU-Japan relations between EPA, IPA and SPA is possible and rational, only from a procedural perspective.

29 It omits (which is hardly surprising), e.g. the challenges to the world order resulting from President Trump's policy; see the statement by Franck-Walter Steinmeier (President of Germany): "And our closest ally, the United States of America, under the present administration, rejects the idea of an international community." Munich Security Conference 2020, https://securityconference.org/en/medialibrary/collection/munich-security-conference-2020/ (access date: 20.12.2019) 
1. EPA and IPA as RTAs. EPA and IPA are considered to be (mutual, preferential) trade liberalizing agreements, known as Regional Trade Agreements - RTA ${ }^{30}$. They belong to the "third wave ${ }^{31}$ " of regionalism ${ }^{32}$. This terminology is WTO-compatible but in the WTO language the term RTA is ambiguous. The term RTA is used to refer to both:

- agreements creating preferences in relations between the Parties irrespective of their geographical distance;

- the conditions under which a WTO member may become a party to the RTA without prejudice to its obligations as a WTO member.

The process of regional institutionalisation is not uniform and does not proceed linearly. The start of the "first wave" was marked by the signature of the GATT and the creation of Benelux. A significant increase in the number of RTAs occurred only at the turn of the 1950s and 1960s. The ECSC, EEC, Euratom, Euratom and EFTA were set up and GATT was institutionalised (for which the GATT acquis was used) ${ }^{33}$. A parallel process was initiated in Central and South America ${ }^{34}$ and Africa ${ }^{35}$. The source of these differences can be found in history and cultural differences. The Parties to the RTAs were - above all - countries belonging to one geographical (or more precisely geopolitical) region. The agreements con-

30 RTAs can be the basis for various agreements, namely: Partial Scope Agreement (duties on selected goods are abolished), Free Trade Agreement (duties and quantitative restrictions in trade are abolished and a free trade area is created), Custom Union (the free trade area is supplemented by a common (external) customs tariff and trade policy) and Economic Integration Agreement (introduces free trade in services).

31 Regionalism is treated as one cycle, in which three sub-cycles, called "waves", are distinguished. See: Edward D. Mansfield, Helen V. Milner, "The New Wave of Regionalism”, International Organizations, Vol. 53, 3(1999), 589-627; Yohanes E. Riyanto, Jung Hur, "On the Explanation of Regionalism Waves", 제42집 3호, December 22, 2019, https://pdfs.semanticscholar.org/e9d8/413ff16d0db90bdda4bda7e07a5ab8ed49f5.pdf.

32 Economic regionalism is defined as an institutionalised process of cooperation that includes the economy. For an overview of definitions see: Edward D. Mansfield, Etel Solingen, "Regionalism", Annual Review of Political Science, 13(2010), 145-163.

33 At the time of so called Dillon's and Kennedy's Rounds.

34 The 1951 agreement between El Salvador and Nicaragua established the Central American Free Trade Area.

35 In 1959, Benin, Burkina Faso, Mali, Mauritania, Niger, Senegal and Côte d'Ivoire established the Union douanière economique des Etats de l'Afrique de l'ouest; (economic customs union of West African states); delay was due to colonialism. 
cluded provided for preferences to be granted to the Parties. Such agreements could be either equal (reciprocal preferences) or unequal (unilateral preferences). Asia differs from this "model", as the process of institutionalization of cooperation began much later, is slower and the processes are less advanced (than in other continents) ${ }^{36}$.

The "second wave" of regionalism that began in the 1980s was to a large extent a response to the crisis of the 1970s, characterised by a combination of inflation and stagnation. In this wave, the WTO was established. During this wave, the economic mechanisms were used ${ }^{37}$. The number of RTAs grew exponentially. The countries focused on regional cooperation as a tool to limit the negative effects of the Uruguay Round. The "second wave" of regionalism was strongly influenced by politics, which both marked the initial caesium and determined its course by the end of the "Cold War" and the socio-economic transformation of the Eastern Bloc member states.

The factors determining the distinction of "second wave" are Parties of the agreements and regulated matters. From the first point of view, the US involvement was crucial ${ }^{38}$. By concluding the RTA, the USA became a precursor to the change in the geographical characteristics of the agreements they set the azimuth for the "third wave", because the first American agreement was interregional (and not regional). The USA initially concluded agreements that did not lead to institutionalisation in the form of an integration organisation, but in the last decade of the 20th century this process entered into the ranks determined by European cooperation (in the form of North American Free Trade Agreement). Argentina, Brazil, Paraguay and Uruguay have created the Mercado Común del Sur, which abolishes tariffs and non-tariff barriers. In Africa, Economic Community of West African States (ECOWAS) and Common Market for Eastern and South-

36 ASEAN primarily institutionalises political cooperation, while trade liberalisation under the Australia New Zealand Closer Economic Relations Trade Agreement excludes sensitive goods. In this case, "backwardness" is balanced by the advancement of cooperation by introducing a uniform regime for determining the origin of goods.

37 Thus, the tried and tested recovery from the crisis without state interventionism was continued, with the model of action rejecting - or at least limiting - Keynesianism.

38 The first US RTA was only concluded in 1985, it was an FTA. On its basis, a free trade area was established between the USA and Israel. 
ern Africa (COMESA) were created. Meanwhile EU members, without creating new institutions, have deepened and broadened European integration (this process is considered to be a symbol of the "second wave") ${ }^{39}$. In the regulated matters, this "wave" was determined by the inclusion of liberalisation of services.

The beginning of the "third wave" is dated to 1995 and is associated with the conclusion of the Uruguay Round and the creation of the WTO. This "wave" includes the EPA, which introduces reciprocal trade preferences ${ }^{40}$.

Conclusion of EPA was actually - an unexpected - consequence of the Uruguay Round ${ }^{41}$. As a result of the "third wave", each WTO member is now also a party to a RTA ${ }^{42}$. The EPA confirms the long-term trend according to which subsequent states or (regional) economic integration organizations $^{43}$ conclude RTAs recognizing that they can achieve more by creating a special regime by means of bilateral regimes than under the WTO multilateral regime. In addition, the EPA, also in the manner typical for RTAs of "third wave", covers in its scope of regulation some of the subject areas in relation to which it was not possible to reach agreement in negotiations at the WTO forum.

One of the key characteristics of "third wave" is that RTAs often include bilateral agreements between Parties located in different continents. When analyzing EPA through the prism of entities participating in it, it is simply a classic case of finding partners geographically distant. This is de-

39 These organisations are customs unions, but in their functioning, apart from undoubted successes, e.g. the advancement of the rules of origin regime (in COMESA), difficulties in achieving the assumed objectives (e.g. the problem of non-tariff barriers in ECOWAS) are also revealed.

40 It is therefore different from PTAs that introduce unilateral preferences. Under the PTAs, developed countries introduced tariff reductions on goods imported from developing countries (mainly in the Generalized System of Preferences - GSP).

41 Of course, this was not the aim of the Uruguay Round, indeed it seems that this effect of the Round surprised the WTO Member States.

42 This process culminated in a RTA between Japan and Mongolia (June 2016). According to the data as of June 2019, there are 294 RTAs notified to WTO and in force. Regional trade agreements, WTO. Retrieved from: https:/www.wto.org/english/tratop_e/ region_e/regfac_e.htm (access date: 27.07.2019).

43 For explanation see: Jerzy Menkes, Andrzej Wasilkowski, Organizacje międzynarodowe. Prawo instytucjonalne, Warszawa: PWN, 2017, 172-174. 
termined by a number of factors, among which it is evident that the stock of partners in the neighbourhood is depleted. An important factor that facilitates the conclusion of RTAs outside the geographical region is the ability to use a model of such agreements which results from the big number of such agreements. RTAs of the "third wave" have de facto created a framework agreement, only modified to individual needs, which speeds up the conclusion of an agreement and reduces costs. RTAs of the "third wave" as bilateral agreements become a serial product in the creation of which the Parties use the "common platform", reducing the costs of creation or use of knowledge.

Another fact proving that EPA can be regarded as an example of the "third wave" of regionalism is that the Parties represent a comparable level of development and economic potential.

One more key feature of "third wave" RTAs is that they cover areas other than only trade in goods. When characterizing the EPA through the scope of regulation, it should be noted that it belongs to the PTA (Preferential Trade Agreement) category, classified as $\mathrm{WTO}+$ (after the transitional period customs duties will be eliminated, i.e. the level of cooperation will be increased - in relation to multilateral obligations - under the current WTO mandate) and WTOx (covering new areas, i.e. going beyond the WTO mandate ${ }^{44}$. The EPA provides rules in areas such as sustainable development with an emphasis on environmental protection, corporate social responsibility, labour standards, facilitations for small and medium enterprises, consumer protection as well as regulatory cooperation or harmonisation of law in areas covered by the Agreement.

In spite of the fact that EPA goes beyond the liberalization of trade in goods and services (which is typical for the agreements of "third wave"), it does it unusually, because the broadening of the scope of normative regulation is significantly greater than in the case of comparable agreements. EPA upgrades the typical RTA model - it is the first RTA to form a relationship with the Paris Climate Agreement (PCA), by including obligations of the Par-

44 Shailja Singh, WTO Plus Commitments in RTAs, Centre for WTO Studies, New Delhi, 2014: March 31, 2019, http://wtocentre.iift.ac.in/CBP/WTO\%20Plus\%20Commitments_Shailja.pdf. 
ties to cooperate - in various forums - in implementation of the PCA. This hard and sharp commitment is important from the perspective of the PCA itself, as it proves that important (and perhaps the main) potential actors of cooperation have decided to sustain and develop it, rejecting the arguments of the opponents and not taking the opportunity to bury it, which was given by the US decision to withdraw from the PCA. It is also important for other international actors (including states), as it is a signal of the expectations of the superpowers (not just economic ones, which are the EU and Japan).

At the same time, the EPA is not a typical RTAs of the "third wave" because it only slightly enlarges and deepens the economic dimension of EU-Japan legal ties. Contrary to other RTAs of this wave, the EPA (without the issues regulated by IPA) does not cover the full scope of regulations regarding investments.

To sum up, the "third wave" RTAs are characterised by: - the geographical distance of the partners; - bilateralism ${ }^{45}$, which can be set against the practice of creating regional organisations ${ }^{46}$; - and the broadening of the scope of the RTAs to include further dimensions of economic cooperation in addition to liberalisation of trade in goods.

2. RTAs and GATT. The new international economic order after the Second World War was founded on a standard prohibiting discriminatory treatment (Articles: I GATT, II GATS and IV TRIPS). The aim was to achieve equal treatment by implementing the prohibition of discrimination. The implementation tool was the application of clauses equalling all partners (countries) or all entities (both domestic and foreign) participating in trade. In the first regime, any privilege granted to one partner was automatically applied to the other beneficiaries under the Most Favoured Nation (MFN) clause. Under the second regime, whose legal framework was determined by the National Treatment clause (NT), domestic and foreign goods, services, trademarks, copyrights and patents had the right to be equally treated on the market of a Party bound by the NT.

GATT, and then the WTO, law therefore aimed to establish a universal regime. The RTAs establishing a preferential regime between the Par-

45 EU RTAs are, in most cases, mixed agreements.

46 This does not mean that such organisations are not created as part of the "third wave", but only that the dynamics of their creation have decreased. 
ties had the character of a specific regime, based either on a bilateral or plurilateral agreement establishing derogations from a certain universal regime as a legal basis. However, the RTAs were not contrary to the universal obligations. The granting of preferences was authorised by the provisions of Article XXIV GATT, the Agreement on the interpretation of Article XXIV GATT 1994, the Enabling Clause and Article V GATS. Article XXIV of the GATT 1947 regulates the establishment of free trade areas and customs unions. The tool to bring preferential RTAs into line with the non-discrimination requirement was GATT Article XXIV, under which the parties to GATT cannot raise barriers to trade of other parties, and a commitment to final liberalisation of trade - including "substantially all the trade" (however, the term used is vague in this case).

3. RTA - PTA (Preferential Trade Arrangement). PTAs differ from RTAs in relation to the obligations assumed by WTO members and in their characteristics.

The legal basis for RTAs under the WTO regime is the dispositions of Article XXIV.5 GATT ${ }^{47}$ and Article V GATS ${ }^{48}$. RTAs standards, in principle, fall within the WSTO framework set of standards. However, many RTAs go beyond this framework both by liberalising trade above the maximum level agreed in the WTO and by regulating matters not regulated by WTO law ${ }^{49}$.

In the case of PTAs, we are dealing with relations that go beyond the scope of WTO obligations. The relationship of these agreements to WTO obligations is reflected in terminology, which is confirmed by

47 This provision protects third countries from a direct deterioration of their situation as a consequence of the conclusion of the RTA. Customs duties in relations with third countries - members of free trade areas or customs unions may not be higher than those in force before the establishment of the free trade area or customs union under the regime of Article XXIV. In general, RTAs must not discriminate against third countries.

48 The disposition of this article determines the designation of the term "economic integration". Article V, which allows the free movement of services, requires the presence of the service provider at the place of supply and the free movement of service providers and customers, requires a deepening of cooperation, lowering the barriers to cooperation to the level necessary for free trade in goods.

49 These may include: environment, labour, investment, competition issues, deepening of cooperation regulated by TRIPs, etc. 
the WTO language ${ }^{50}$. At the same time, within the PTAs set, stratification takes place. There are distinguished: - multilateral agreements that create commitments going beyond what is agreed in multilateral fora, e.g. with regard to further tariff reductions, defined as WTO-plus (WTO+); agreements in which the parties have regulated issues outside the scope of the WTO mandate, such as, for example, the setting of labour standards. These agreements are labelled as WTO-extra (WTOx) ${ }^{51}$.

In the case of WTO+ PTAs, the parties to the agreements do not merely commit themselves to liberalising trade by lowering custom duties, but, taking advantage of the transition periods, completely eliminate them. In these agreements, the parties manage to agree, for example, on the issue of certificates of origin and the implantation of these arrangements by the customs administration ${ }^{52}$. The strength of the PTAs is that they regulate matters on which there is no consensus in the WTO multilateral forum; for example, no agreement was reached in the Uruguay Round on certificates of origin. WTO+ agreements have also established a prohibition of export duties, which are not prohibited by the WTO law.

WTOx PTAs often contain non-mandatory standards that are declarations of intent and forward-looking. Such a legal state constitutes the use of the term "shall" in the text of the agreement - the dispositions of such a norm are not only not self-executable, but also questionable. In the case of a standard whose instruction includes a statement "... the parties shall cooperate...", it is not possible to assess the behaviour of the Parties in terms of the performance of contractual obligations (because it is not possible to state neither the fact of cooperation between the Parties nor the fact that there is no such cooperation). Such provisions - common in PTAs - change their character from traités-contrat or descriptive traités-loi

50 See: Shailja Singh, WTO Plus Commitments in RTAs, Centre for WTO Studies, New Delhi, 2014, March 31, 2019, http://wtocentre.iift.ac.in/CBP/WTO\%20Plus\%20 Commitments_Shailja.pdf.

51 See: Herik Horn, Petros C. Mavroidis, André Sapir, Beyond the WTO? An Anatomy of EU and US Preferential Trade Agreements, Vol. VII, Brussels: Bruegel Blueprint Series, 2009.

52 In this case, in the WTO+ PTAs the EU establishes a joint body to determine the rules of origin, while in the WTO regime, in the absence of institutional cooperation mechanisms, EU members implement the regulations individually - they are only obliged not to discriminate. 
to prescriptive traités-loi (forming a program). The indicated provisions do not set out the rights and obligations of the Parties, but political and moral obligations. Beyond the scope of the substantive legal framework defining the WTO regime, there are, for example, obligations to coordinate the social systems or social development of the Parties.

The above distinction of RTAs to WTO+ and WTOx PTAs is model-based and not all the elements mentioned are always present in a single agreement, nor can they occur in different combinations.

The EPA is a "third wave" RTAs standard. It contains the standards that characterise both WTO+ and WTOx. This is determined by the fact that its regulations cover, inter alia, sustainable development and environmental protection (with emphasis on environmental protection), labour standards and employee rights, facilitations for small and medium enterprises and consumer protection, as well as approximation or harmonisation of the law in the areas covered by the Agreement. EPA encourages not only sustainable development but also the implementation of values such as corporate social responsibility. The EPA (it can be assumed that IPAs as well) - typically for this "wave" of agreements - goes beyond the scope of liberalisation agreements on trade in goods and services, and do so atypically, as the extension of the scope of normative regulation of EPA is significantly greater than for comparable agreements ${ }^{53}$. The EPA contains commitments by the Parties to cooperate - in various fora - with regard to the implementation of the Paris Climate Agreement. This firm commitment is important from the perspective of the Paris Agreement itself, as it shows that important (and perhaps the main) actors of potential cooperation have decided to maintain and develop this cooperation, rejecting the arguments of the opponents and not taking the opportunity to bury it as a result of the US decision to withdraw from the Agreement. This is also important for other international actors, as it is a signal of the expectations of the powers (not only the economic ones, which are the EU and Japan). However, contrary to the declaration, there remains the lack of any real commitment from Japan to implement the Paris Climate Agreement ${ }^{54}$.

53 Such as UE-Viet Nam FTA, EU-Singapore FTA\&IPA.

54 In practice, Japan's policy (consisting, among other things, in a return to coal in the energy sector and a move away from nuclear power) is still closer to American than 


\section{WHO?}

The socio-economic potential of the new market is 637 million people (8,5\% of world total) and 27 trillion USD of GDP (based on purchasing power parity, PPP), which is $21 \%$ of the world's GDP. In market prices, Japan and the EU together account for around a third of the world economy. In terms of GDP and population the EU is about four times larger than Japan (see table 1). At the same time, Japan is the 3rd richest economy in the world (by GDP) after USA and China ${ }^{55}$.

Table 1. The economic size of EU-28 and Japan, 2018

\begin{tabular}{|l|c|c|}
\hline & EU-28 & Japan \\
\hline GDP, current prices, billion USD & 18768 & 4971 \\
\hline GDP, PPP (current international USD, billions) & 22447 & 5415 \\
\hline GDP per capita (current USD) & 36570 & 39290 \\
\hline GDP per capita, PPP (current international USD) & 43738 & 42797 \\
\hline GDP, current prices, share of world total (in \%) & 21,8 & 5,8 \\
\hline GDP based on PPP, share of world total (in \%) & 16,5 & 4,0 \\
\hline Population, mln persons & 513 & 127 \\
\hline
\end{tabular}

Source: World Development Indicators, World Bank, https://databank.worldbank.org/ $(23.02 .2020)$

Both the EU and Japan are developed, industrialised democracies, sharing common values like the rule of law, with strong economic and

European policy; see: Valerie Volcovici, "At climate talks, Japan's Koizumi confronts critics over coal", Reuters. December 9, 2019 https://www.reuters.com/article/us-climatechange-accord-japan/at-climate-talks-japans-koizumi-confronts-critics-over-coal-idUSKBN1YF2KG; Eric Johnston, "At Madrid climate talks, Japan's Shinjiro Koizumi confronts critics over coal", The Japan Times. December 12, 2019, https://www.japantimes.co.jp/ news/2019/12/12/national/science-health/madrid-climate-talks-japans-shinjiro-koizumiconfronts-critics-coal/\#.XIFWrC16OWg.

55 Germany and United Kingdom are the fourth and fifth. Gross domestic product 2018. Retrieved from: https://databank.worldbank.org/data/download/GDP.pdf (access date: 10.03.2019). 
political links, and closely cooperating with one another in international and multilateral fora such as the UN, the WTO, the G7 and G20 ${ }^{56}$. Japan is one of the EU's closest partners and a strategic partner in the Asia-Pacific region.

Table 2. EU-28 main trade partners, 2018 (USD billion and \%)

\begin{tabular}{|c|c|c|c|c|c|c|c|}
\hline & Exports/goods & $\begin{array}{c}\text { Value in } \\
\text { billion } \\
\text { USD }\end{array}$ & $\begin{array}{c}\text { Share } \\
\text { of } \\
\text { total }\end{array}$ & & Imports/goods & $\begin{array}{c}\text { Value in } \\
\text { billion } \\
\text { USD }\end{array}$ & $\begin{array}{c}\text { Share } \\
\text { of } \\
\text { total }\end{array}$ \\
\hline & World & 6468 & 100 & & World & 6411 & 100 \\
\hline 1 & United States & 480 & 7,4 & 1 & China & 465 & 7,3 \\
\hline 2 & China & 247 & 3,8 & 2 & United States & 317 & 4,9 \\
\hline 3 & Switzerland & 186 & 2,9 & 3 & Russian Federation & 198 & 3,1 \\
\hline 4 & Russian Federation & 101 & 1,6 & 4 & Switzerland & 130 & 2,0 \\
\hline 5 & Turkey & 92 & 1,4 & 5 & Norway & 99 & 1,5 \\
\hline 6 & Japan & 76 & 1,2 & 6 & Turkey & 90 & 1,4 \\
\hline 7 & Norway & 64 & 1,0 & 7 & Japan & 83 & 1,3 \\
\hline 8 & Rep. of Korea & 59 & 0,9 & 8 & Rep. of Korea & 60 & 0,9 \\
\hline 9 & India & 54 & 0,8 & 9 & India & 54 & 0,8 \\
\hline 10 & Canada & 49 & 0,8 & 10 & Vietnam & 45 & 0,7 \\
\hline
\end{tabular}

Source: Direction of Trade Statistics (DoTS), International Monetary Fund

Japan is the EU's $2^{\text {nd }}$ biggest trading partner in Asia after China ${ }^{57}$. However, it is the EU's only $7^{\text {th }}$ most important trading partner worldwide $\left(6^{\text {th }}\right.$ in extra-EU exports and $7^{\text {th }}$ extra-EU imports, see table 2 ), while

56 The Economic Impact of the EU - Japan Economic Partnership Agreement (EPA). An analysis prepared by the European Commission's Directorate-General for Trade, European Commission 2018. Retrieved from: http://trade.ec.europa.eu/doclib/docs/2018/july/ tradoc_157116.pdf (access date: 15.05.2019).

57 The increased importance of cooperation with Japan compared to the higher potential of cooperation with China results from the analysis of the overall relations with Japan as compared to relations with China. The effects of trade, and more broadly economic cooperation of the EU (as well as the USA) with China, vary. On the one hand, trade serves the economic development of the parties, on the other hand, in a situation where China 
the EU is Japan's $3^{\text {rd }}$ trading partner $\left(3^{\text {rd }}\right.$ in exports and $2^{\text {nd }}$ in imports - see table 3).

Table 3. Japan's main trade partners, 2018 (USD billion and \%)

\begin{tabular}{|c|c|c|c|c|c|c|c|}
\hline \multicolumn{2}{|r|}{ Exports/goods } & $\begin{array}{l}\text { Value in } \\
\text { billion } \\
\text { USD }\end{array}$ & $\begin{array}{l}\text { Share } \\
\text { of total }\end{array}$ & & Imports/goods & $\begin{array}{c}\text { Value in } \\
\text { billion } \\
\text { USD }\end{array}$ & $\begin{array}{l}\text { Share } \\
\text { of total }\end{array}$ \\
\hline \multicolumn{2}{|r|}{ World } & 738 & 100 & \multicolumn{2}{|r|}{ World } & 776 & 100 \\
\hline 1 & China & 144 & 19,5 & 1 & China & 174 & 22,4 \\
\hline 2 & United States & 141 & 19,1 & 2 & EU & 88 & 11,3 \\
\hline 3 & EU & 84 & 11,3 & 3 & United States & 84 & 10,8 \\
\hline 4 & Rep. of Korea & 52 & 7,1 & 4 & Australia & 46 & 5,9 \\
\hline 5 & Taiwan & 42 & 5,7 & 5 & Saudi Arabia & 34 & 4,4 \\
\hline 6 & Hong Kong & 35 & 4,7 & 6 & Rep. of Korea & 32 & 4,1 \\
\hline 7 & Thailand & 32 & 4,4 & 7 & Taiwan & 28 & 3,6 \\
\hline 8 & Singapore & 23 & 3,2 & 8 & UAE & 28 & 3,6 \\
\hline 9 & Australia & 17 & 2,3 & 9 & Thailand & 25 & 3,2 \\
\hline 10 & Vietnam & 16 & 2,2 & 10 & Indonesia & 22 & 2,8 \\
\hline
\end{tabular}

Source: Direction of Trade Statistics (DoTS), International Monetary Fund

So there is an untapped potential in EU-Japan trade relations which was at the core of the decision to launch negotiations for a bilateral trade agreement. EPA, by abolishing tariff and non-tariff barriers to EU's and Japan's markets, opens up new opportunities resulting from expanding markets. The importance of EPA for Parties is affected by the share of trade in their GDP. In case of the EU trade accounts for almost $85 \%$, while the world average is $56 \%$ (see figure 1). For Japan the corresponding number is much less $-31 \%^{58}$.

does not fully respect free trade rules (WTO obligations), trade with China is a source of threats for the EU, the US and Japan.

58 This low share in case of Japan is due to the collapse of the Japanese exports after 2008. It was a combined effect of the global downturn in 2008 and a natural disaster earthquakes in the pacific coast of the Tōhoku region (11/03/2011) and the nuclear power plant disaster in Fukushima. 
Figure 1. Trade openness of Japan, EU-28 and world, 2005-2016

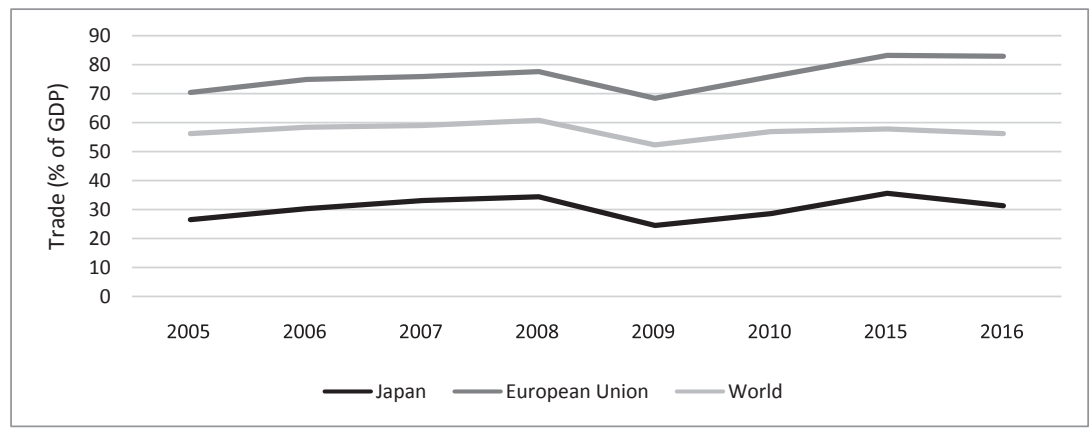

Source: own work based on World Development Indicators, World Bank

Fast growth of trade and GDP of both partners can be forecasted as a result of implementing EPA. In 2012, the Commission forecasted that the cumulative economic effect of all (then) negotiated FTAs would exceed 250 billion euro, increasing the EU's GDP by $2 \%$ (equivalent to the GDP of Austria or Denmark ${ }^{59}$. The prognosis is supported both by the use of widely recognised quantitative methods in economic research and by the EU's experience in implementing similar agreements. Customs duties account for approximately $2 \%$ of EU exports to Japan. A reduction in customs protection may translate into increased employment in companies manufacturing goods and services exported to Japan. This is important in a context where 0.6 million jobs are already derived from trade with Japan and where, of the 74000 or so companies exporting to the Japanese market, $78 \%$ are small businesses, for which the cost of entry is of particular importance.

The common tool used in empirical studies for assessing the economic impact of liberalisation of trade (elimination or reduction of customs duties) is GTAP (Global Trade Analysis Project) model. The standard GTAP Model is a multiregion, multisector, Computable General Equilibrium

59 Karel De Gucht, Why we should open free trade negotiations with Japan. Retrieved from: http://europa.eu/rapid/press-release_SPEECH-12-562_en.htm?locale=en (access date: 10.03.2019). 
model, assuming perfect competition, constant returns to scale,product differentiation by countries of origin - the so-called Armington assumption.

The idea of general equilibrium dates back to Leon Walras (1834-1910). It takes into account the fact that markets interact with each other, and therefore markets and its components are interdependent. For example, demand for any one good depends on the prices of all other goods and on income, which in turn depends on wages, profits and rent, etc. The CGE (Computable General Equilibrium) approach allows for taking into account the complexity of the markets (contrary to other approaches which require many simplifications). However, this can be done by the expense of simplification of the characterization of economic behaviour. CGE models express all economic relationships in mathematical terms and allow to predict changes of different variables resulting from a change in economic policies $^{60}$. The models analyse the effects of trade policy taking into account the main links between sectors as well as between the domestic and international production of goods and services. The efficiency gains from trade liberalisation can be captured, as the reallocation of the factors of production (capital, labour and land) across sectors and between countries (domestic-foreign) is tracked. The way the models are constructed allows to compare the impact of hypothetical changes in trade policy on costs, prices or income to a certain "baseline" (i.e. the scenario with no policy changes). One should be aware however, that the results should be treated only as indications of the magnitude of expected impact of trade agreements. The CGE models do not capture the potential expansion of trade in new products and services or any welfare gains from access to a greater variety of final products. They also do not take into account the long-term effects, such as greater incentives to innovate ${ }^{61}$.

60 GTAP Models: Computable General Equilibrium Modeling and GTAP. Retrieved from: https://www.gtap.agecon.purdue.edu/models/current.asp (access date: 20.07.2019).

${ }_{61}$ The Economic Impact of the EU - Japan Economic Partnership Agreement (EPA). An analysis prepared by the European Commission's Directorate-General for Trade, European Commission 2018. Retrieved from: http://trade.ec.europa.eu/doclib/docs/2018/july/ tradoc_157116.pdf (access date: 15.05.2019). 
The theoretical framework of the GTAP model was presented by Herte $^{62}$, and updated later on by Corong et al. ${ }^{63}$ Dynamic version of the model incorporates international capital mobility and capital accumulation. GTAP modelling is widely used for bilateral tariff reduction analysis. E.g. Tongzon $^{64}$ assessed the trade implications of China's WTO membership for developing ASEAN countries, Siriwardana and Yang ${ }^{65}$ analysed the effects of the proposed Australia - China Free Trade Agreement. There are also several studies of the EPA impact using GTAP model ${ }^{66}$. The advantage of the most recent one, prepared by the European Commission's Directorate-General for Trade and published in $2018^{67}$, is that it includes provisions actually negotiated by the EU and Japan in the EPA.

62 Thomas W. Hertel (ed.), Global Trade Analysis: Modeling and Applications, New York: Cambridge University Press, 1997.

63 Erwin L. Corong, Thomas W. Hertel, Robert McDougall, Marinos E. Tsigas, Dominique van der Mensbrugghe, "The Standard GTAP Model, Version 7", Journal of Global Economic Analysis, Vol. 2, 1(2017), 1-119.

${ }^{64}$ Jose L. Tongzon, "China’s Membership in the World Trade Organization (WTO) and the Exports of the Developing Economies of East Asia: A Computable General Equilibrium Approach", Applied Economics, Vol. 33, 15(2001), 1943-1959.

65 Mahinda Siriwardana, Jinmei Yang, "GTAP Model Analysis of the Economic Effects of an Australia-China FTA: Welfare and Sectoral Aspects", Global Economic Review, Vol. 37, 3(2008), 341-362.

${ }^{66}$ For example: Eva R. Sunesen, Josef F. Francois, Martin H. Thelle, Assessment of barriers to trade and investment between the EU and Japan. Final report, Copenhagen: Economics, 2010; Trade Sustainability Impact Assessment of the Free Trade Agreement between the European Union and Japan. Final Report, European Commission, Directorate-General for Trade 2016; Gabriel Felbermayr, Fukunari Kimura, Toshihiro Okubo, Martina Steininger, Erdal Yalcin, On the Economics of an EU-Japan Free Trade Agreement, Study of the Ifo Institute on behalf of the Bertelsmann Foundation, Final Report on March 3, 2017; Eliza Przeździecka, Rumiana Górska, Andżelika Kuźnar, Jerzy Menkes, The effects of EU-Japan economic partnership agreement for Poland's economy, "Ekonomista" 6(2019), 701-733; The Economic Impact of the EU - Japan Economic Partnership Agreement (EPA). An analysis prepared by the European Commission's Directorate-General for Trade, European Commission 2018. Retrieved from: http://trade.ec.europa.eu/doclib/ docs/2018/july/tradoc_157116.pdf (access date: 15.05.2019).

67 The Economic Impact of the EU - Japan Economic Partnership Agreement (EPA). An analysis prepared by the European Commission's Directorate-General for Trade, European Commission 2018. Retrieved from: http://trade.ec.europa.eu/doclib/docs/2018/july/ tradoc_157116.pdf (access date: 15.05.2019). 
According to the simulations, by 2035 (when EPA is fully implemented) EU's GDP will increase by almost 34 billion euro more (or extra $0.14 \%$ ) and Japanese economy will grow by 29 billion euro more (or $0.6 \%$ ) when compared to the situation with no agreement. This is also accompanied by an increase of EU exports to Japan by about 13 billion euro (13\%) and of Japanese exports to the EU by about 23 billion euro $(23 \%)^{68}$. The relative positive impact is larger for Japan which may be attributed to the smaller size of this economy and the fact that Japan is a relatively smaller trade partner for the EU (see Table 2 and Table 3).

The results are sector-specific. Table 4 presents the economic impact of EPA in terms of output in various sectors, while table 5 illustrates the impact for bilateral trade in the same sectors. According to the results presented in table 4, the EU's sector that would benefit the most from the implementation of EPA are business services (13 billion euro by 2035). Some other services sectors are also among the top beneficiaries. The reason for that is that many services are intermediate inputs used in other sectors, which exports may increase due to the Agreement. Therefore, even if exports of business services is not expected to increase by large extent, there are still possible gains in this sector of the European economy. The sector that is expected to grow the most (by 2\%) are the textiles, apparel and leather. In this sector tariffs that EU companies were facing in Japanese market were relatively high (over $21 \%$ on average). However, Japan eliminated duties on textiles and clothing immediately upon entry of the Agreement into force. It has also (in March 2015), adopted an international textiles labelling system similar to the one used in the EU. Therefore the costs of entry to Japan's market for European exporters will decrease. There are two sectors that lose from the agreement: cereals (marginally) and motor vehicles. The latter one may be negatively affected by increased imports from Japan. However, it is expected that vehicle sector exports to Japan will increase thanks to the reductions in non-tariff measures (see table 5). Not surprisingly, the very same sector is going to gain most in Japan (in terms of output).

68 Ibidem. 
Table 4. The economic impact of the EU-Japan EPA in 2035, by sector output ( $\%$ and million $€$ )

\begin{tabular}{|l|r|r|r|r|}
\hline & \multicolumn{2}{|c|}{ EU } & \multicolumn{2}{c|}{ Japan } \\
\cline { 2 - 5 } & $\%$ & $\begin{array}{c}\text { Absolute change } \\
\text { (million } \boldsymbol{\epsilon})\end{array}$ & $\%$ & $\begin{array}{c}\text { Absolute change } \\
\text { (million } \boldsymbol{\epsilon})\end{array}$ \\
\hline Rice & 0.0 & 2 & -0.0 & -3 \\
\hline Cereal grains & -0.0 & -6 & -0.4 & -2 \\
\hline Other Primary & 0.0 & 78 & -0.1 & -61 \\
\hline Livestock & 0.2 & 278 & -0.6 & -119 \\
\hline Meat & 0.2 & 725 & -0.5 & -162 \\
\hline Fishery & 0.0 & 5 & -0.0 & -5 \\
\hline Dairy & 0.3 & 1054 & -1.5 & -505 \\
\hline Beverages and Tobacco & 0.2 & 535 & 0.2 & 196 \\
\hline Processed Food & 0.2 & 1841 & -0.2 & -493 \\
\hline Textile, Apparel and Leather & 1.9 & 7096 & -2.2 & -1327 \\
\hline Wood & 0.2 & 2187 & 0.4 & 841 \\
\hline Chemicals & 0.1 & 1975 & 1.2 & 6235 \\
\hline Motor Vehicles & -0.0 & -139 & 2.5 & 13861 \\
\hline Transport Equipment & 0.0 & 30 & 2.4 & 1221 \\
\hline Electronic Equipment & 0.1 & 328 & 0.6 & 2093 \\
\hline Metal Products & 0.1 & 805 & 1.1 & 2424 \\
\hline Machinery and equipment & 0.1 & 1307 & 1.0 & 5362 \\
\hline Ferrous Metal products & 0.1 & 272 & 0.9 & 3113 \\
\hline Other Manufacture & 0.2 & 949 & 0.9 & 676 \\
\hline Minerals and glass & 0.1 & 3103 & 0.8 & 5565 \\
\hline Other Transp. and travel agencies & 0.1 & 2400 & 0.5 & 2819 \\
\hline Air Transport & 0.1 & 307 & 0.3 & 187 \\
\hline Water Transport & 0.1 & 601 & 0.3 & 524 \\
\hline Business services & 0.2 & 12844 & 0.8 & 11174 \\
\hline Communication & 0.1 & 1123 & 0.4 & 1154 \\
\hline Trade & 0.1 & 6943 & 0.7 & 10436 \\
\hline Finance and Insurance & 0.1 & 2831 & 0.6 & 3355 \\
\hline Construction & 0.3 & 9423 & 1.5 & 9150 \\
\hline Other Services & 0.1 & 6150 & 0.1 & 4614 \\
\hline & & & & \\
\hline
\end{tabular}

Source: The Economic Impact of the EU - Japan Economic Partnership Agreement (EPA). An analysis prepared by the European Commission's Directorate-General for Trade, European Commission 2018, p. 50. Retrieved from: http://trade.ec.europa.eu/doclib/docs/2018/ july/tradoc_157116.pdf (access date: 15.05.2019). 
The EPA will cause the largest increase in the EU absolute exports to Japan in textiles..., chemicals, motor vehicles, processed food and dairy. For Japan, the sectors that will increase their exports to the EU the most include: motor vehicles, machinery and equipment, chemicals, minerals and glass and metal products. That means that for Japan the main gains are in manufacturing industrial goods while in the EU the benefits are more diversified and located in many sectors that often do not benefit the most from trade policy, e.g. agriculture, beverage, textile, apparel and leather products $^{69}$.

Table 5. Impact of EPA in 2035 on EU-Japan bilateral trade, by sectors

(\% and million $€$ )

\begin{tabular}{|l|r|r|r|c|}
\hline \multirow{2}{*}{} & \multicolumn{2}{|c|}{ EU } & \multicolumn{2}{c|}{ Japan } \\
\cline { 2 - 5 } & $\%$ & $\begin{array}{c}\text { Absolute change } \\
\text { (million } € \text { ) }\end{array}$ & $\%$ & $\begin{array}{c}\text { Absolute change } \\
\text { (million } € \text { ) }\end{array}$ \\
\hline Rice & -0.1 & 0 & 0.1 & 0 \\
\hline Cereal grains & 1.5 & 0 & 22.1 & 0 \\
\hline Other Primary & 27.6 & 55 & 22.1 & 21 \\
\hline Livestock & 9.0 & 7 & 2.0 & 0 \\
\hline Meat & 73.4 & 337 & 22.5 & 14 \\
\hline Fishery & 6.9 & 2 & 4.3 & 2 \\
\hline Dairy & 215.0 & 729 & 170.0 & 5 \\
\hline Beverages and Tobacco & 10.2 & 260 & 7.1 & 2 \\
\hline Processed Food & 51.8 & 1095 & 38.2 & 67 \\
\hline Textile, Apparel and Leather & 220.0 & 5213 & 63.2 & 337 \\
\hline Wood & 21.8 & 635 & 20.1 & 69 \\
\hline Chemicals & 6.9 & 1606 & 30.0 & 3306 \\
\hline Motor Vehicles & 11.5 & 1222 & 51.3 & 8174 \\
\hline Transport Equipment & 0.9 & 15 & 30.3 & 991 \\
\hline Electronic Equipment & 1.3 & 25 & 6.9 & 437 \\
\hline & & & & \\
\hline
\end{tabular}

69 The Economic Impact of the EU - Japan Economic Partnership Agreement (EPA). An analysis prepared by the European Commission's Directorate-General for Trade, European Commission 2018, 52. Retrieved from: http://trade.ec.europa.eu/doclib/docs/2018/ july/tradoc_157116.pdf (access date: 15.05.2019). 


\begin{tabular}{|l|r|r|r|r|}
\hline \multirow{2}{*}{} & \multicolumn{2}{|c|}{ EU } & \multicolumn{2}{c|}{ Japan } \\
\cline { 2 - 5 } & $\%$ & $\begin{array}{c}\text { Absolute change } \\
\text { (million } \boldsymbol{~} \text { ) }\end{array}$ & $\%$ & $\begin{array}{c}\text { Absolute change } \\
\text { (million } \boldsymbol{\text { } )}\end{array}$ \\
\hline Metal Products & 16.4 & 443 & 31.9 & 1321 \\
\hline Machinery and equipment & 2.0 & 237 & 13.6 & 3576 \\
\hline Ferrous Metal products & 2.7 & 13 & 0.8 & 8 \\
\hline Other Manufacture & 23.7 & 261 & 20.1 & 184 \\
\hline Minerals and Glass & 26.7 & 725 & 83.0 & 3018 \\
\hline Other Transp. and travel agencies & 1.7 & 14 & 2.9 & 20 \\
\hline Air Transport & 0.2 & 5 & 0.4 & 9 \\
\hline Water Transport & 1.4 & 77 & 2.8 & 39 \\
\hline Business services & 2.2 & 264 & 3.0 & 150 \\
\hline Communication & 3.6 & 22 & 2.4 & 4 \\
\hline Trade & 1.9 & 85 & 3.4 & 171 \\
\hline Finance and Insurance & 3.3 & 107 & 5.3 & 96 \\
\hline Construction & 2.4 & 79 & 6.2 & 191 \\
\hline Other Services & 0.5 & 8 & 0.2 & 2 \\
\hline
\end{tabular}

Source: The Economic Impact of the EU - Japan Economic Partnership Agreement (EPA). An analysis prepared by the European Commission's Directorate-General for Trade, European Commission 2018, p. 51. Retrieved from: http://trade.ec.europa.eu/doclib/docs/2018/ july/tradoc_157116.pdf (15.05.2019).

However, the entry into force of EPAs is not only a tool for obtaining economic benefits ${ }^{70}$.

\section{HOW (MODUS OPERANDI) AND WHY (LIKE THAT)?}

The EU and Japan are continuing the two-way process of creation of a legal framework for mutual relations and implementation of legal and

70 Although it is worth to remember that EU exports are subject to $€ 1$ trillion duty and this revenue to Japan's budget will disappear. The context of the agreement, i.e. the links to TPP, TTIP and to Brexit is analysed by Hitoshi Suzuki, The new politics of trade: EU-Japan, "Journal of European Integration", 2017, 39 (7), 875-889http:// eprints.lse.ac.uk/87318/1/Suzuki_New\%20Politics\%20of\%20Trade\%20EU-Japan.pdf (access date: 22.12.2019). 
political standards covered by existing commitments. It is a long-lasting process with variable dynamics. This process encountered many different barriers, among which EU's public opinion pays particular attention to the triangle (US-EU-Japan ${ }^{71}$ ) of interests and interactions as well as potential economic challenges, not always recognizing the importance of cultural differences in the sphere of functioning of both individuals and society. Awareness of the difficulties associated with cultural differences ${ }^{72}$, however, was not perceived by the EU and Japan as an insurmountable obstacle but as a challenge that can be faced together. This has been demonstrated by the proposals of deregulation ${ }^{73}$ of the Japanese economy presented by the Commission ${ }^{74}$, as a way to refloat the economy suffering from the Asian financial crisis. The European response to the Japan's economic problem was not schadenfreude when the economic rival suffered the troubles (in politics, Japan was - even informally - a strategic ally of the EU as part of the "western hemisphere"). We consider these particular European propos-

71 The tops of this triangle are strategic allies, being at the same time extremely different. The US is (still) the only - perhaps China will achieve this rank - hyperpower in the strategic dimension, remaining a national state (see more: Parag Khanna, The End of the Nation-State, The New York Times, October 14, 2013, https://www.nytimes. com/2013/10/13/opinion/sunday/the-end-of-the-nation-state.html; Rana Dasgupta, The demise of the nation state, "The Guardian", 05.04.2018). The EU and Japan are - at best the superpowers-the beneficiaries of American security guarantees. At the same time, when the world returns to the Hobbesian culture of rivalry, the USA, using the instruments of unilateralism, confronts with more and more new players of the "axis of evil", while the EU and Japan, adhering to Wilsonian values and methods, follow the path of multilateralism (see also: Robert Kagan, Of Paradise and Power. America and Europe in the New World Order, New York: Alfred A. Knopf, 2003; Robert Kagan, "America's Crisis of Legitimacy", Foreign Affairs, Vol. 83, 2(2004), 65-87).

72 On fundamental values see: César de Prado, "Towards a Substantial EU-Japan Partnership", European Foreign Affairs Review, 22(4)(2017), 446-452. In this area, the abolition of the death penalty (p. 451) was a difficult issue, but it was closely linked to the waiting for the death penalty to be carried out on 7 perpetrators of the terrorist sarin attack in the Tokyo subway in 1995.12 people were murdered in the attack (5,000 were injured).

73 The deregulation dialogue between the EU and Japan has developed since its official establishment in 1994 and is continued.

${ }^{74}$ List of EU Deregulation Proposals for Japan, Commission of the European Communities. 12.10.1998. Retrieved from: http://trade.ec.europa.eu/doclib/docs/2004/ march/tradoc_111837.pdf (access date: 20.06.2018). 
als as the starting point in the calendar of works on the subject-matter of the agreements researched in this paper. The essence of the proposal was the willingness to help Japan in carrying out the institutional transformation, which was to lead to get out of the crisis and to initiate the economic growth thanks to - among others - restoring confidence in the economy. Apart from the content of the proposal, it was important that the Parties have mutual confidence in each other and are capable of dialogue in matters falling within the internal sphere of the state ${ }^{75}$ (demonstrated by the proposal and positive reaction to it). In bilateral contacts, the Parties searched for what is common or for what brings them closer to each other, not what differentiates them ${ }^{76}$. This way - with the use of official, semi-official and unofficial contacts - the EU and Japan led to the entry into force (January 1, 2002) of the Mutual Recognition Agreement ${ }^{77}$. The agreement, by limiting non-tariff barriers, facilitated trade in goods. The Parties analysed the effects of the implementation of the MRA and the possibilities of cooperation in relation to trade and investment ${ }^{78}$ and launched public consultations devoted to deepening of ties ${ }^{79}$.

75 The document contained not only proposals, but also assessments of Japanese actions and their results.

76 See Commissioner Lamy's speech of 9.03.2000: “As I have said before, our societies spring from similar roots. We have a shared vision of the kind of national and international society that we want. We share a common attachment to freedom, democracy, the rule of law and human rights - and it comes from a shared culture." Retrieved from: http://trade. ec.europa.eu/doclib/docs/2004/november/tradoc_120146.pdf (access date: 11.01.2003).

77 Agreement on Mutual Recognition Between Japan and The European Community), MOFA, 04.04.2001. Retrieved from: https:/www.mofa.go.jp/region/europe/eu/ agreement.pdf (access date: 15.03.2019).

78 Joseph Francois, Miriam Manchin, Hanna Norberg, Economic impact assessment of an FTA between the EU and Japan. February 2011. Retrieved from: http://trade.ec.europa.eu/doclib/docs/2017/july/tradoc_155782.pdf (access date: 15.03.2019). In the analysis, the authors used the CGE (Computable General Equilibrium) model of general equilibrium, taking into account not only "shocks" related to the elimination of customs duties (tariff barriers), but also estimated effects of the elimination of non-tariff barriers. The co-author, Prof. Francois, is one of the most outstanding European economists specializing in research on world trade

79 See: Summaries of contributions to the Public Consultation on: The future of EU Japan trade and economic relations. 17.02.2011. Retrieved from: http://trade.ec.europa. eu/doclib/docs/2011/february/tradoc_147586.pdf (access date: 18.03.2019). 
The political impulse for the EPA negotiations were the arrangements made during the 20th EU-Japan Meeting (May 2011). It took a year to agree on the agenda (until May 2012), and the subsequent months passed on the EU internal procedures ${ }^{80}$. However, initially the objectives of the Parties were different; the EU assumed the conclusion of a FTA, Japan pursued an $\mathrm{EPA}^{81}$. The official start of negotiations was on 25.03.2013 ${ }^{82}$, and the first round of negotiations took place in Brussels on 15-19.04.2013. Although the Parties declared "toughness" 83 in the negotiations, and even readiness to withdraw from them, the talks were conducted quickly and the will to reach the agreement was evident. Works on the agreement were carried out in the " 4 steps" formula (Preparing, Negotiating, Finalising, Signing ${ }^{84}$ ), i.e.: 1) the EC submitted to the Council an application for the negotiating directives; 2) the Council adopted negotiating directives, and indicated the Commissions to conduct negotiations; 3) negotiations;

80 The Negotiating Directive was adopted on 29 November 2012.

81 The decision was influenced by external political factors. Japan was the only Asian country to join the US and EU sanctions against Russia after the annexation of Crimea (of course, this is also connected with the Japan-Russia dispute over the so-called "Northern Territories"). More: Kazuto Suzuki, "Perspectives on an Uncertain World: Japan-EU Views on the United States and Russia", Instituto Affari Internationali Commentaries, 18, 21.03.2018. Retrieved from: https://www.iai.it/en/pubblicazioni/perspectives-uncertainworld-japan-eu-views-united-states-and-russia (access date: 20.06.2019).

82 Joint statement by the President of the European Commission, José Manuel Barroso, the President of the European Council, Herman Van Rompuy, and the Prime Minister of Japan, Shinzo Abe. Retrieved from: http://europa.eu/rapid/press-release_IP-13-276_ en.htm (access date: 15.05.2019).

83 Sometimes on the verge of ridicule, as in Commissioner K. De Gucht's Statement (from 18. 06. 2012): „I have made it very clear to my colleagues today that after one year of starting the negotiations, we will take stock on the progress Japan has made on dismantling the non- tariff barriers as set out in the roadmap we have agreed together. If the implementation has not been satisfactory, I will stop the negotiations. I don't think we can be any clearer than that in our ambitions. I have also made clear that Europe would not reduce any tariffs before Japan delivers concrete results on regulatory barriers - and this includes the car sector. So we will walk to the negotiation table with a very strong starting position."; - European Commissioner Karel De Gucht

${ }_{84}$ Negotiating EU trade agreements. Who does what and how reach a final deal. Retrieved from: http://trade.ec.europa.eu/doclib/docs/2012/june/tradoc_149616.pdf (access date: 8.04.2019). 
4) after obtaining the authorization from the Parties, the agreement was initially signed (it is a co-decision of the Council and Parliament) ${ }^{85}$. Already after the start of the negotiations, it was decided to exclude from the agreement the domain of investment protection ${ }^{86}$ and negotiate it separately; it was negotiated by another team led by M. Martin-Prat. This separation creates a new model for the conclusion of EU trade agreements ("free trade agreements architecture"), under which, according to the ECJ ruling of 16.05.2017, the issues falling within the exclusive competence of the EU were separated from the shared competences, where the concluded agreement is a mixed agreement.

The negotiations of EPA itself in its truncated version took about 5 years $^{87}$. The head of EU team of negotiators was by R. M. Petriccione ${ }^{88}$. SPA $^{89}$ negotiations lasted 5 years $^{90}$ - the team of negotiators was led by V. I. Budura and were completed (17 June 2018) by signing of the agreement. In the case of this agreement, the Parties decided - referring, however, to an empty symbolism - to point out the longstanding cooperation that preceded the SPA and recalled in the Preamble the 1991 Joint Declaration on relations between the EC and its Member States and Japan, although this was not followed by any significant practice.

85 EU-Japan Economic Partnership Agreement. How it works. Retrieved from: http://ec.europa.eu/trade/policy/in-focus/eu-japan-economic-partnership-agreement/ meetings-and-documents/ (access date: 8.04.2019).

${ }_{86}$ This took place in 2016 during the negotiations and was accompanied by the establishment of new negotiating teams; see: Report of the 15th EU-Japan FTA/EPA negotiating round Brussels, 29 February - 4 March 2016, point 7. Retrieved from: http://trade. ec.europa.eu/doclib/docs/2016/march/tradoc_154368.pdf(access date: 8.04.2019).

${ }_{87}$ There have been 18 rounds of negotiations. Negotiations were concluded on 8 December 2017 and the signature of the agreement took place on 6 June 2018 during the EU-Japan summit.

${ }^{88}$ Deputy Director-General of the European Commission, Directorate-General for Trade. He retained the position of Chief Negotiator, taking the position of Director in the Asia-Pacific region.

89 The idea was formulated as a result of the 20th EU-Japan Summit in 2010, at which the Parties recognised themselves as like-minded global partners and "Kizuna" (the bonds of friendship).

90 They were rapidly accelerated in 2017. 


\section{WEIGHT OF THE AGREEMENTS}

In a world where instability is increasing and security is reduced, the Parties to the agreements (EU and Japan) meet their obligations as global civilian powers, bearing special responsibility for the implementation of the goals and represented values ${ }^{91}$. The agreements are a tool for defending international order against actions / persons threatening it. The cooperation of the Parties proves the spill-over effect ${ }^{92}$. The Parties have recognized that the cooperation is a source of benefits. The agreements not only refer to values, but - potentially - they also strengthen and institutionalize these values.

In the western hemisphere, and consequently in the world, the paradigm of international relations is being questioned, that the necessary condition for achieving peace and justice - the values declared by the societies and countries of the "western hemisphere" as desirable in international relations - is "free and fair trade" 93 . The co-author of this paradigm was the USA, and this country, as part of its policy of leadership, worked to implement it. This paradigm was associated with the possibility of socio-economic and political transformations in the world, resulting in an increase in the wealth of individuals and societies, economic development and respect for fundamental human rights and freedoms, and justice ${ }^{94}$. The scale and direction of the change in all parameters of social development that co-existed with the implementation of the paradigm ${ }^{95}$ is so significant

91 See Lord Castlereagh's view on the role and functions of the great powers; see Charles K. Webster (ed.), British Diplomacy 1813-1815. Selected Documents Dealing with the Reconciliation of Europe. Sagwan Press. 2015.

92 See: Ernst B. Haas, "International Integration. The European and Universal Process”, International Organizations, 15(1961), 367-368.

93 Critical view see: Alexander Hamilton, "Concerning Dangers from Dissensions Between the States", Federalist, 6(1786-1800). Retrieved from: https://www.congress. gov/resources/display/content/The+Federalist+Papers\#TheFederalistPapers-6 (access date: 15.07.2018).

94 See: Kenneth N. Waltz, Structural Realism after the Cold War, "International Security", Vol. 25, 1(2000), 7, Retrieved from: http://www.columbia.edu/itc/sipa/U6800/ readings-sm/Waltz_Structural\%20Realism.pdf (access date: 15.07.2018).

${ }_{95}$ More: Christopher Layne, "Kant or Cant. The Myth of the Democratic Peace", International Security, Vol. 19, 2(1994), 5. 
that it can be identified with influence ${ }^{96}$. A multi-element (because it encompasses principles that shape the political- and socio-economic system) regime of "western" values influenced both internal and external relations. Relations between countries belonging to the "west" can be treated as evidence of a positive verification of the "Dell hypothesis" time, the United States' potential has grown throughout this period, and the country has eventually become an essential hyperpower ${ }^{98}$. The American leadership also included the role of an intermediary in the transcontinental relations of the Allies. Transcontinental political and socio-economic relations of European, Asian and (both) Americas' countries belonging to the "west" were maintained (predominantly) via the USA.

All this structure - including values, norms, institutions and practices - is consistently demolished by President Trump. The rejection (or at

96 Fukuyama has defined this as an ideal correlation; Francis Fukuyama, "Liberal Democracy as a Global Phenomenon", Political Science and Politics, Vol. 24, 4(1991), 662.

${ }_{97}$ According to it: „No two countries that are both part of a major global supply chain, like Dell's, will ever fight a war against each other as long as they are both part of the same global supply chain". This concept has been generalised in modern times by Thomas L. Friedman to "McDonald's theory of international relations", according to which no country in which McDonald's operates will ever attack the (other) country in which McDonald's is located. See: Thomas L. Friedman, The World is Flat. A Brief History of the Twenty-first Century, New York: Farrar, Straus, Giroux, 2005, 421. It is based on the conviction that participation in the global value chain is an expression of the integration of the domestic economy with the global economy and of cultural openness, which determines the economic unprofitability of war. This hypothesis extends by economic principles the catalogue of systemic factors eliminating the use of armed force in interstate disputes. In the past, these principles included only those that defined the political system. See: Kenneth N. Waltz, Structural Realism after the Cold War, 7 („The democratic peace thesis holds that democracies do not fight democracies. Notice that I say "thesis," not "theory." The belief that democracies constitute a zone of peace rests on a perceived high correlation between governmental form and international outcome.").

98 See: Secretary of State Madeleine K. Albright Interview on NBC-TV "The Today Show" with Matt Lauer, 19.02.1998, U.S. Department of State. Retrieved from: https://1997-2001.state.gov/statements/1998/980219a.html (access date: 14.04.2018) and Immanuel Wallerstein, “The Curve of American Power”, New Left Review, 40(2006), pp. 77-94, Retrieved from: http://www.iwallerstein.com/wp-content/uploads/ docs/NLRCURVE.PDF (access date: 10.05.2018); Joseph S. Nye Jr., "Amerikas Macht", In: Empire Amerika - Perspektiven einer neuen Weltordnung, ed. Ulrich Speck, Natan Sznaider, Stuttgart: Deutsche Verlags-Anstalt, 2003, 156-172. 
the very least the undermining) of the values and norms, underpinning US policy and American alliances has put US strategic partners in the European and Pacific regions in the position of having to compensate for the US vacuum, caused by neo-isolationism and interdependent downgrading ${ }^{99}$. Under these conditions, a transpacific bridge ${ }^{100}$ connecting the EU with Asia is being built. This bridge - potentially, after the end of turbulence in US policy - will allow to create a stable triangle of the states of two oceans (Atlantic and Pacific). The strategic triangle is a desirable response to threats to stability and security in the world. The states of this space can institutionalize the security community, ensuring their nations the sustainable development and protecting the remaining ones from the effects of the safety vacuum ${ }^{101}$.

From the perspective of these threats, it is particularly important to uphold the rules of "free and fair" trade and to institutionalize the community of values between the EU and Asian countries. The EU-Japan agreements (together with, inter alia, the EU-Vietnam, Singapore, New Zealand and Australia agreements) are, in this perspective, an important tool for the implementation of the indicated values-standards ${ }^{102}$. At the same time, they are an element of building a deep trans-regional bond. The Parties are convinced of the possibility - limited in time - of substituting the role of the US in maintaining the "west" by creating by-passes connecting the Allies from the regions of Europe, America (Canada and

99 For example, for the first time in the history of the United States of America, a "permanent member" of the Security Council did not receive the support of a single member of the SC in the vote on its proposed project. See: Press Release, S.C./13362, 01.06.2018. Retrieved from: https:/www.un.org/press/en/2018/sc13362.doc.htm (access date: 14.04.2018).

100 This bridge could become a mirror version of the (Atlantic) bridge connecting the EU and the US. See: Robert J., "Art, Fixing Atlantic Bridges", Foreign Policy, 46(1982), 67-85.

${ }^{101}$ Future (direct) EU-Japan security cooperation will complement the US and Japan cooperation as well as Japan and NATO cooperation. In the NATO-Japan formula, the participants consider themselves as "natural partners". See: Individual Partnership and Cooperation Programme between Japan and NATO https:/www.mofa.go.jp/mofaj/ files/000382902.pdf (access date: 22.02.2020).

102 The EU's relations with the countries of the Asia region include a broad and growing range of actors. 
the countries at the south of Rio Grande del Norte), Asia and the Pacific, maintaining order, value and paradigm ${ }^{103}$. They see the possibility to meet the challenges of both strategic rivals (China, Russia) and the strategic partner (USA). The EU (and its Member States) and Japan are connected by common values and co-create a functional security community ${ }^{104}$.

Political (western) relations between Europe and Japan, from the perspective of Europe, were directly related to US-Japan relations. Despite the community of values ${ }^{105}$, principles and interests, these relations were always de facto maintained by and with the participation of a third party the USA. The integrating Europe recognised Japan not only as an American sphere of influence, but also as an exclusive responsibility of the USA. The paradox of the second half of the twentieth century was the turning away of the Parties which already in the nineteenth century co-created the international community as fully-fledged actors ${ }^{106}$. At the same time, the postwar pacifism of Japan, combined with the constitutional restrictions on activity and political and military potential granted by the USA, resulted in a long-term absence of Japan from world politics in its international activities. For decades, Japan has been a "big mute" in world politics - at the same time being a great payer, a state that stands out in a humanitarian and development assistance. However, both Japanese silence and Japanese action were not perceived by public opinion to an extent proportional to the scale of phenomena. An indirect testimony to this is the low ranking of Japan in the institutional structures of the United Nations System, which is inadequate, among other things, for its financial contribution. What the public perceived in Europe with regard to Japan was its economic activity. Relatively rapid evolution of the Japanese economy from an imitator to an innovator, from a producer and seller of low-quality

${ }^{103}$ Looking forward to the return of the USA to the strategy presented by Richard L. Armitage, Joseph S. Nye Jr., The U.S.-Japan Alliance. Getting Asia Right through 2020, CSIS, February 2007.

${ }^{104}$ As the Euro-Asian institutional security community was not built.

105 The SPA preamble confirms "REAFFIRMING their commitment to the common values and principles, in particular, the democracy, human rights and fundamental freedoms".

106 Japan after the Treaty of Shimonoseki (in 1895) was recognized as a "great power" by the European powers. 
cheap products to a competitor in the rivalry for market dominance was arousing - effectively fomented and strengthened by European economic entities - fears of failure in competition with Japan. As a result, Europe erected an economic wall that was supposed to separate (protect) it from $\operatorname{Japan}^{107}$, while in the political and security sphere it did not build bridges connecting it with Japan. The economic policy of Japan was a mirror image of this. Contrary to so many and such important factors connecting the EU and Japan, these actors remained for decades at a distance, which was only partly due to the geographical distance. The process of establishing and institutionalising relations between European countries and Japan was slow and not linear.

\section{THE AGREEMENTS IN THE PRISM OF PLURI- AND MULTILATERAL RELATIONS}

The Asia-Pacific region is at the forefront of the ranking of regions according to the criterion of conflict potential. This is determined by the co-occurrence of a set of factors, including the number of countries with military nuclear capability and states capable of immediate production of it. Among the countries of the region with military nuclear capability are Russia, China, India, Pakistan, North Korea, USA, and capable of producing it immediately are: Japan and South Korea ${ }^{108}$. The countries of the region with significant military potential are conducting disputes, including territorial disputes, such as those between India and Pakistan, Japan and Russia, China-neighbourhood ${ }^{109}$. Some of these territorial disputes are in a state of hibernation, in others the parties are on the point of confrontation. In this region there are fallen states, active terrorists, and

${ }^{107}$ Analogous to that erected by Japan.

108 This accounts for 2/3 of the total number of nuclear states, as France, Great Britain and Israel are outside the region.

${ }_{109}$ Among other things, China controls trade routes in the South China Sea and is building fortifications on disputed islands (e.g. in the Spratly Islands between Vietnam and the Philippines). 
drugs produced ${ }^{110}$. The level of danger is enhanced by the fact that North Korea is a contra-system (in relation to a system based on international law) ${ }^{111}$. These factors determine the level of security threats.

The importance of the region increased after the Cold War, as a consequence of the concentration of nuclear threats in the region, international terrorism, organized crime and significant instability. These threats, in the context of the situation in other regions, determined the American pivot towards Asia ${ }^{112}$. After the end of World War II, the US assigned significant importance to the East Asia, South East Asia and Pacific region. The allies in the region were to be beneficiaries and co-creators of regional and global stability. The presence of the USA in the region was of a military (defensive) and political nature.

President Trump has rejected this strategy. The change was to include the withdrawal from the transpacific plurilateral agreements in the economic and social sphere, the contestation of cooperation in the sphere of security, undermining the unconditional nature of security guarantees

110 The first opium producer in the world is Afghanistan and the second is Myanmar; World Drug Report, UNODC, 2017. Retrieved from: https://www.unodc.org/wdr2017/ (access date: 20.04.2018).

${ }^{111}$ In its National Defense Strategy, the US once again uses the term rogue state to describe this country: "Rogue regimes such as North Korea and Iran are destabilizing regions through their pursuit of nuclear weapons or sponsorship of terrorism. North Korea seeks to guarantee regime survival and increased leverage by seeking a mixture of nuclear, biological, chemical, conventional, and unconventional weapons and a growing ballistic missile capability to gain coercive influence over South Korea, Japan, and the United States. In the Middle East, Iran is competing with its neighbors, asserting an arc of influence and instability while vying for regional hegemony, using state-sponsored terrorist activities, a growing network of proxies, and its missile program to achieve its objectives"; see: Summary of the National Defense Strategy. Sharpening the American Military's Competitive Edge, Department of Defense, 2018. Retrieved from: https://www.defense.gov/ Portals/1/Documents/pubs/2018-National-Defense-Strategy-Summary.pdf (access date: 20.10.2018).

112 This regional and global policy was named by the Obama administration pivot to Asia. Kenneth Lieberthal, The American Pivot to Asia, Foreign Policy, December 21, 2011, https://foreignpolicy.com/2011/12/21/the-american-pivot-to-asia/ (access date: 1.12.2019). 
for the countries of the region ${ }^{113}$ and the rejection of the free trade paradigm. It was initiated by the termination ${ }^{114}$ of the Trans-Pacific Partnership (TPP) ${ }^{115}$. The decision raised doubts not only as to economic rationality but also to the way international policy was conducted. Unilaterality and brutality demonstrated disregard for the partners. In this situation the USA's announcement of the willingness to conclude bilateral trade agreements with TPP parties disregarded the assessment of the US's ability to conclude international agreements in the assessment of potential parties. Trump, confronted with reality, had to give up the declared strategy quickly. Already in November 2017, in a speech at the APEC summit, Trump presented a vision of a "free and open Indo-Pacific ${ }^{116 "}$ to strengthen the friendship and trade ties between all Indo-Pacific nations, where trade will be based on "fairness and reciprocity"117. 2017 closed with a radical turnaround in foreign policy. The National Security Strategy (NSS) ${ }^{118}$ pre-

113 The President raised the obligation to participate in the costs of ensuring security (Peter Baker, "Trump Says NATO Allies Don't Pay Their Share. Is That True?", The New York Times, 26.05.2017. Retrieved from: https://www.nytimes.com/2017/05/26/world/ europe/nato-trump-spending.html (access date: 14.04.2018). Directly on the conditionality of the security guarantee see: David E. Sanger, Maggie Haberman, "Donald Trump sets conditions for defending NATO Allies against attack”, New York Times, July 20, 2016. Retrieved from: https:/www.nytimes.com/2016/07/21/us/politics/donald-trump-issues. html (access date: 14.04.2018).

${ }_{114}$ Presidential Memorandum regarding withdrawal of the United States from Trans-Pacific Partnership Negotiations and Agreement, 23.01.2017. Retrieved from: https://www.whitehouse.gov/presidential-actions/presidential-memorandum-regarding-withdrawal-united-states-trans-pacific-partnership-negotiations-agreement/ (access date: 10.04.2018).

115 Agreement regulating trade relations, signed on 4.02.2016 between: Australia, Brunei Darussalam, Chile, Canada, Japan, Malaysia, Mexico, New Zealand, Peru, Singapore, USA and Vietnam.

116 The US has therefore supported Prime Minister Shinzo Abe's initiative.

117 Remarks by President Trump at APEC CEO Summit, The White House, 10.11. 2017. Retrieved from: https://www.whitehouse.gov/briefings-statements/remarkspresident-trump-apec-ceo-summit-da-nang-vietnam/ (18.03.2019).

${ }_{118}$ National Security Strategy of USA, The White House, 2017. Retrieved from: https:/www.whitehouse.gov/wp-content/uploads/2017/12/NSS-Final-12-18-2017-0905. pdf (access date: 18.03.2019). 
sented by the President ${ }^{119}$ identifies new, major threats to the US security. The source of them is no longer terrorism ${ }^{120}$ but great power competition with "revisionist powers", China and Russia ${ }^{121}$. The response to Chinese hegemony and the aggressive policy of Russia - the authoritarian states that were considered "strategic competitors" - is to be an army whose potential in the region is to be significantly increased. The decision is based on the recognition that the US has enduring interests and commitments in the Indo-Pacific region ${ }^{122}$, regardless of financial contributions.

The NSS positively assessed the balance of 75 years of cooperation with the allies (in the Pacific and European region) ${ }^{123}$. Australia, South

119 Remarks by President Trump on the Administration's National Security Strategy, The White House, 18.12.2017. Retrieved from: https://www.whitehouse.gov/briefings-statements/remarks-president-trump-administrations-national-security-strategy/ (access date: 18.03.2019). It's analysis in: Anthony H. Cordesman, "President Trump's New National Security Strategy", Center for Strategic \& International Studies, 18.12.2017. Retrieved from: https://www.csis.org/analysis/president-trumps-new-national-security-strategy (access date: 19.03.2019).

120 Weights assigned to threats have been changed: „States are the principal actors on the global stage, but non-state actors also threaten the security environment with increasingly sophisticated capabilities. Terrorists, trans-national criminal organizations, cyber hackers and other malicious non-state actors have transformed global affairs with increased capabilities of mass disruption”.

121 "China and Russia are now undermining the international order from within the system by exploiting its benefits while simultaneously undercutting its principles and 'rules of the road'." Summary of the National Defense Strategy. Sharpening the American Military's Competitive Edge, U.S. Department of Defense, 2018, https://www.defense. gov/Portals/1/Documents/pubs/2018-National-Defense-Strategy-Summary.pdf (access date: 20.03.2019).

${ }^{122}$ General Joseph Dundorf - the chairman of the Joint Chiefs of Staff stated „If you look at the health of our alliances in the region... The evidence reflects anything other than a decline in Pacific power. We have enduring interests here, we have enduring commitment and an enduring presence in the Pacific." "US power not in decline across Asia-Pacific: Dunford", AFP, Feb. 6, 2018, https://www.shephardmedia.com/news/defence-notes/uspower-not-decline-across-asia-pacific-dunford/ (access date: 10.03.2019).

123 „Mutually beneficial alliances and partnerships are crucial to our strategy, providing a durable, asymmetric strategic advantage that no competitor or rival can match. This approach has served the United States well, in peace and war, for the past 75 years. Our allies and partners came to our aid after the terrorist attacks on 9/11, and have contributed to every major U.S.-led military engagement since. Every day, our allies and partners 
Korea, India, Japan and New Zealand are strategic partners of the USA in the region. In the NSS, the US also attached great importance to the cooperation of the Indo-Pacific countries in the new formula of the plurilateral institution - cooperation of four: Australia, India, Japan and the USA.

New in the U.S. strategy is the name of the region: "Asia-Pacific" has been replaced by "Indo-Pacific" 124 . The term (used with regard to the safety of shipping) is unclear. What is clear, however, is the inclusion of India in the cooperation ${ }^{125}$ (although the decisions were not preceded by any consultations with India ${ }^{126}$ ), which, however, reinforces China's fears of a being encircled and expresses its support for India in its rivalry with Paki$\operatorname{stan}^{127}$. The assessment of the decision is ambiguous ${ }^{128}$, but it undoubtedly hinders cooperation with China in relations with North Korea ${ }^{129}$. The US

join us in defending freedom, deterring war, and maintaining the rules which underwrite a free and open international order." Summary of the National Defense Strategy. Sharpening the American Military's Competitive Edge, U.S. Department of Defense, 2018, https://www. defense.gov/Portals/1/Documents/pubs/2018-National-Defense-Strategy-Summary.pdf (access date: 20.03.2019).

124 The author of the term is an Indian Navy officer Gurpeet S. Khurrana, but he referred it to sea shipping routes. Gurpeet S. Khurana, "Security of Sea Lines: Prospects for India-Japan Cooperation”, Strategic Analysis, vol. 31, 1 (2007), 139.

${ }^{125}$ A state that was not in alliance with the USA, has broken the NPT regime and is evolving into an authoritarian religious republic.

${ }^{126}$ India's position, see: Jonathan Eyal, "Japan-India: An Alliance with a difference”, The Straits Time, 07.11.2016. Retrieved from: http://www.straitstimes.com/opinion/japan-india-an-alliance-with-a-difference (access date: 1.12.2017).

127 Who is a necessary ally in the fight against terrorism in Afghanistan.

${ }^{128}$ More: Bhavan Jaipragas, "Why is the US calling Asia-Pacific the Indo-Pacific? Donald Trump to 'Clarify”, 07.11.2017. Retrieved from: http://www.scmp.com/weekasia/politics/article/2118806/why-us-calling-asia-pacific-indo-pacific-trump-clarify (access date: 1.12.2017); Rory Medcalf, “The Indo-Pacific. What's in a Name? Brookings”, October 2013. Retrieved from: https://www.brookings.edu/articles/the-indo-pacific-whats-ina-name/ (access date: 16.06.2017).

${ }^{129}$ Secretary of State of the United States R. Tillerson stated that Chinese provocations in the South China Sea, in violation of international law, are not only directed against the sovereignty of the neighbours, but also harm the interests of the US and its friends; more broadly, they are directed against the sovereignty of the neighbours and against the interests of the US and its friends. More: Nicole Gaouette, "Tillerson raps China as 'predatory' rule breaker", CNN Politics, 19.10.2017. Retrieved from: http://edition.cnn.com/2017/10/18/politics/tillerson-china-rebuke-speech/index.html (access date: 
also refers to the Japanese Prime Minister Shinzo Abe's initiative to describe Asia as "Asia's democratic security diamond".

Of course, arguments for a change of terminology in correlation with a change of strategy can be put forward. If we consider that the world's economic centre of gravity is shifting towards Asia, then, given the relationship between geo-economics and ocean space, it determines the importance of the Indo-Pacific zone. There is no doubt that the Indo-Pacific is a real geopolitical structure with geo-economic significance. The geopolitical continuity of the Indian and (Western) Pacific oceans in all spheres, including security, is beyond doubt ${ }^{130}$. China's supply routes pass through the Indian Ocean, which allows the Indian Navy to attribute the ability to influence Chinese policy. This dependence was noticed by Prime Minister Abe already in $2007^{131}$. The new nomenclature (new strategy) is also supported by legitimate expectations towards India ${ }^{132}$, which are unjustifiably depreciated in the Asia-Pacific strategy.

Democratic Asian and Pacific states and the EU want to be co-creators of the new order. Japan advocated the institutionalization of multilateralism (de facto plurilateralism). The withdrawal of the US from the TPP has stimulated the activity of participants of cooperation. An alternative form of institutional economic cooperation was created. On 8 March 2018, 11 countries (TPP minus the US) signed the Comprehensive and Progressive Agreement for Trans-Pacific Partnership (CPTPP) ${ }^{133}$. The Agreement

1.12.2017); Patricia Lourdes Viray, "US: We will not ignore China's challenge to rulesbased order", The Philippine Star, 19.10.2017. Retrieved from: http://www.philstar.com/ headlines/2017/10/19/1750399/us-we-will-not-ignore-chinas-challenge-rules-based-order (access date: 1.12.2017).

${ }^{130}$ The economy of East Asia is dependent on resources from West Asia and Africa being transported through the Indian Ocean. The transfer of weapons and technology between bandit countries links West Asia and the rest of the world. (Iran, Syria) with East Asia (North Korea).

${ }^{131}$ Address to the Indian Parliament. Shinzo Abe, "Confluence of Two Seas", Ministry of Foreign Affairs of Japan, 22.08.2007. Retrieved from: http://www.mofa.go.jp/region/ asia-paci/pmv0708/speech-2.html (access date: 16.06.2017).

${ }^{132}$ Although in the Indo-Pacific term, the word "Indo" is synonymous with the ocean, not the state.

${ }^{133}$ Since the beginning of 2019 the CPTPP is in force between Australia, Canada, Japan, Mexico, New Zealand, Singapore and Vietnam. 
is a typical "third wave" RTA going beyond the liberalisation of trade in goods and services. It also regulates labour issues, environmental protection and public procurement. However, it is not that the CPTPP is exactly the same agreement as TPP was supposed to be. The ambition of President Barack Obama was to create a (new) pattern of world trade by means of TPP. The TPP consisted of 30 chapters covering - apart from the liberalization of trade in goods and services - everything from labour standards to intellectual property rights. The CPTPP is narrower (22 TPP provisions were suspended), but the agreement proves the parties' ability to cooperate ${ }^{134}$. The CPTPP can be the foundation of the institutionalisation of regional cooperation, the start of integration, starting with reconciliation between the states in conflicts in the past. TPP11 also turns out to be attractive to other countries in the region, whose accession will strengthen CPTPP. Intention to join "11" declares South Korea, Bangladesh, Philippines, India, Cambodia, Colombia, Indonesia, Laos, Sri Lanka and Thailand.

From the EU perspective, the collapse of the TPP process as a consequence of the US decision represented a threat to the global order and cooperation with the countries of the Asia-Pacific region. It could have turned out that the position of the US will be taken by China (and that this situation will be of benefit to Russia). The CPTPP puts these threats aside. Thanks to the CPTPP, its Parties weigh more (both in economic and security terms) than the sum of the unit weights (synergy effect). The Parties to the CPTPP and the EU are attractive partners to each other.

In the case of Japan, the EU-Japan partnership represents a major policy change. Japan's foreign policy has evolved from bilateral cooperation with the US to expanding the circle of partners under the "Arc of Freedom and Prosperity" formula. The new partnership means de facto lowering the importance of cooperation with the US and losing hope for a broad partnership with the countries indicated in the "Arc of Freedom

${ }^{134}$ More: "What on earth is the CPTPP", The Economist, 12.03.2018. Retrieved from: https://www.economist.com/blogs/economist-explains/2018/03/economist-explains-8 (access date: 15.03.2019). 
and Prosperity" ${ }^{135}$. This is determined both by President Trump's policy and the collapse of the trend leading to the sharing of common values by many non-Western countries (especially Russia and China) ${ }^{136}$.

EU economic cooperation in the form of "third wave" RTAs with South Korea, Japan, Singapore (concluded) and with Australia and New Zealand (in the process of negotiations) is a response to economic challenges related to globalization and the challenges of new economic powers (especially China).

In the sphere of security, an attempt was made to fill - potentially the vacuum created after the withdrawal of American security guarantees. Withdrawal of the US is to be compensated by cooperation, the beginning of which (since May 2017) has been patrolling the Pacific waters by the US, Japan, France and Great Britain ${ }^{137}$. In addition, the United Kingdom in the face of Brexit shows interest in cooperating with CPTPP ${ }^{138}$. The reactions of European allies to the Japanese proposal to deepen cooperation by going beyond the sphere of economic relations and the institutionalization of ties in the sphere of security and defence policy are clearly positive ${ }^{139}$.

Trans-regional economic, political and defence cooperation between the EU and the Asian countries of the Western hemisphere creates the con-

135 This idea was formulated by the government headed by Junichiro Koizumi (predecessor and mentor of Shinzo Abe); see: Tomohiko Taniguchi, "Beyond "The Arc of Freedom and Prosperity": Debating Universal Values in Japanese Grand Strategy, The German Marshall Fund of the United States", Asia Paper Series, October 2010, http://www.gmfus.org/publications/beyond-arc-freedom-and-prosperity-debating-universal-values-japanese-grand-strategy (access date: 1.12.2019).

136 See: Speech by Mr. Taro Aso, Minister for Foreign Affairs on the Occasion of the Japan Institute of International Affairs Seminar "Arc of Freedom and Prosperity: Japan's Expanding Diplomatic Horizons”, November 30, 2006, https://www.mofa.go.jp/ announce/fm/aso/speech0611.html (access date: 22.02.2020).

137 David Hutt, “The 'Indo-Pacific' Vision: Room for Britain And France?”, Forbes, 14.11.2017. Retrieved from: https://www.forbes.com/sites/davidhutt/2017/11/14/the-indo-pacific-vision-room-for-britain-and-france/ (access date: 18.04.2018).

${ }^{138}$ Julia Gregory, "Britain exploring membership of the TPP to boost trade after Brexit”, The Guardian, 03.01.2018. Retrieved from: https://www.theguardian.com/politics/2018/jan/03/britain-in-talks-to-join-the-tpp-to-boost-trade-after-brexit (access date: 18.04.2018).

139 See: Emil J. Kirchner, Han Dorussen, EU-Japan Security Cooperation. Trends and Prospects, London-New York: Routledge, 2019. 
ditions for stopping destabilization and strengthening security in the regional and global dimension.

\section{CONCLUSIONS}

The Agreements institutionalise the EU-Japan security community a Pacific bridge where the security and defence policy component is still relatively weak, but is also being developed ${ }^{140}$. The three agreements making closer political and economic ties between the UE and Japan open the way to the creation of the EU's security community with "democratic diamonds" in the Asia-Pacific region. The importance of the Agreements is co-decided by:

- endogenous factors, resulting from economic and political potentials of the Parties;

- exogenous factors, in the form of external determinants of cooperation.

Exogenous factors do indeed give meaning to the agreements. These factors include: turbulence in the US policy combined with the US abandonment of international commitments and contestation of values fundamental for the Western community; unpredictability of Russia in the Russian hegemonic policy; and China's hegemony.

We find that the Agreements are a tool for the defence of international order against threats. The political context of the agreements is determined by the US policy in relation to regions and problems, which is in contradiction with long-term strategy of the US. This is a source of instability, particularly dangerous for the strategic actions of the rivals of the "west", challenging the international order. The US, rejecting the paradigm of free and fair trade and collective self-defence of the free world, put the Allies in a safety vacuum and made them unable to face threats. In addition, it happened under Trump's neo-isolationism policy and under the conditions of undermining US obligations.

140 See more: Andżelika Kuźnar, Jerzy Menkes, „Indo-Azja-Pacyfik - instytucjonalizacja współpracy”, In: Handel i finanse międzynarodowe w świetle wyzwań XXI wieku, ed. Małgorzata Bartosik-Purgat, Alicja Hadryś-Nowak, Warsaw: CeDeWu, 2018, 63-74. 
The Agreements pave the way for a strategic partnership between the EU and Japan, co-creating an EU security community with "democratic diamonds" in the Asia-Pacific region. At the same time, the Agreements protect against the emergence of a safety vacuum.

The Agreements additionally activate Japan, in the desired direction, from the point of view of EU interests, by changing its political orientation. Japan ceases to be a „big mute in world politics”, taking on global responsibility in cooperation with the EU.

Cooperation between Parties proves the spill-over effects. The EPA is especially source of economic and social benefits, but it also creates the unprecedented ties in EU-Asia relations which are comparable with EU-US relations. Entry into force of the EPA is beneficial for all Parties from the point of view of: - direct impact on the economy (bilateral relations); - indirect impact, as it strengthens the position of the Parties in cooperation with strategic partners and in global competition; - influence on the power of the Parties.

The Agreements do not create a rigid legal framework for cooperation. It may be a subject to both deepening and broadening. We claim that Asia and Pacific countries and the EU, when confronted with the threat (above all the American neo-isolationism), show the ability to independently take up the challenge. This cooperation, leading to the construction of a transpacific bridge, may become - after the return of the US to traditional policy - a pillar of the cooperation of the states of the Atlantic and Pacific Oceans. The EU and the Asian countries, by creating a network of contractual links, give a new content to the statement by John Hay (US Secretary of State 1898-1905) that "The Mediterranean ${ }^{141}$ is the ocean of the past, The Atlantic, the ocean of the present, and the Pacific, the ocean of the future". This future can be better - different from the Atlantic past filled with human tragedies ${ }^{142}$.

${ }^{141}$ It was a metaphor of the unilateral order (limited to Europe).

${ }^{142}$ More: Jean-Pierre Lehmann, Valérie Engammare, "Beyond Economic Integration: European Lessons for Asia Pacific?” The Globalist, 03.02.2014. Retrieved from: https:// www.theglobalist.com/beyond-economic-integration-european-lessons-asia-pacificl (access date: 13.03.2017). 


\section{REFERENCES}

Abe Shinzo. Confluence of Two Seas, Ministry of Foreign Affairs of Japan, 22.08.2007. https://www.mofa.go.jp/region/asia-paci/pmv0708/speech-2.html Art Robert J. 1982. "Fixing Atlantic Bridges". "Foreign Policy" 46: 67-85.

Baker Peter. ”Trump Says NATO Allies Don't Pay Their Share. Is That True?” . The New York Times", April 14, 2018 https://www.nytimes.com/2017/05/26/ world/europe/nato-trump-spending.html.

Cordesman Anthony H. "President Trump's New National Security Strategy". "Center for Strategic \& International Studies", 18.12.2017. https://www.csis. org/analysis/president-trumps-new-national-security-strategy.

Corong Erwin L., Hertel Thomas W., McDougall Robert, Tsigas Marinos E., van der Mensbrugghe Dominique. 2017. "The Standard GTAP Model, Version 7". "Journal of Global Economic Analysis" 1: 1-119.

Dasgupta Rana. "The demise of the nation state". "The Guardian", 05.04.2018. https:/www.theguardian.com/news/2018/apr/05/demise-of-the-nationstate-rana-dasgupta.

De Gucht Karel. "Why we should open free trade negotiations with Japan". March 10, 2019 (spacja) http://europa.eu/rapid/press-release_SPEECH-12-562_en.htm?locale=en.

de Prado Yepes Cesar. 2017. "Towards a Substantial EU-Japan Partnership", "European Foreign Affairs Review” 22(4): 446-452.

Eyal Jonathan. "Japan-India: An Alliance with a difference". "The Straits Time", 07.11.2016. http://www.straitstimes.com/opinion/japan-india-an-alliance-with -a-difference.

Felbermayr Gabriel, Kimura Fukunari, Okubo Toshihiro, Steininger Martina, Yalcin Erdal. "On the Economics of an EU-Japan Free Trade Agreement, Study of the Ifo Institute on behalf of the Bertelsmann Foundation", Final Report on March 3, 2017.

Francois Joseph, Manchin Miriam, Norberg Hanna. "Economic impact assessment of an FTA between the EU and Japan", February 2011. http://trade. ec.europa.eu/doclib/docs/2017/july/tradoc_155782.pdf.

Friedman Thomas L. 2005. The World is Flat. A Brief History of the Twenty-first Century. New York: Farrar, Straus and Giroux.

Fukuyama Francis. 1991. "Liberal Democracy as a Global Phenomenon". "Political Science and Politics" 4.

Gaouette Nicole. "Tillerson raps China as 'predatory' rule breaker", "CNN Politics”, 19.10.2017. http://edition.cnn.com/2017/10/18/politics/tillerson-china-rebuke-speech/index.html. 
Gregory Julia. "Britain exploring membership of the TPP to boost trade after Brexit". "The Guardian", 03.01.2018. https://www.theguardian.com/politics/2018/jan/03/britain-in-talks-to-join-the-tpp-to-boost-trade-after-brexit. Haas Ernst B.1961. "International Integration. The European and Universal Process". "International Organizations" 15: 367-368.

Hamilton Alexander. Concerning Dangers from Dissensions Between the States, "Federalist" 6. July 15, 2018 https://www.congress.gov/resources/display/ content/The+Federalist+Papers\#TheFederalistPapers-6.

Hertel Thomas W. 1997. Global Trade Analysis: Modeling and Applications. New York: Cambridge University Press.

Horn Herik, Mavroidis Petros C., Sapir André. 2009. An anatomy of EU and US preferential trade agreements, Brussels: Bruegel Blueprint Series.

Hubner Kurt, Balik Tugce, Deman Anne-Sophie. 2016. "CETA: the Making of the Comprehensive Economic and Trade Agreement Between Canada and the EU". "Notes de l'Ifri”"April: 7-34. https://www.ifri.org/sites/default/files/ atoms/files/notes_ifri_ceta.pdf.

Hutt David. "The 'Indo-Pacific' Vision: Room for Britain And France?”. "Forbes". 14.11.2017. https:/www.forbes.com/sites/davidhutt/2017/11/14/the-indopacific-vision-room-for-britain-and-france/.

Jaipragas Bhavan. "Why is the US calling Asia-Pacific the Indo-Pacific? Donald Trump to "Clarify". 07.11.2017. http://www.scmp.com/week-asia/politics/ article/2118806/why-us-calling-asia-pacific-indo-pacific-trump-clarify.

Johnston Eric. "At Madrid climate talks, Japan's Shinjiro Koizumi confronts critics over coal”. "The Japan Times". December 12, 2019. https://www.japantimes. co.jp/news/2019/12/12/national/science-health/madrid-climate-talks-japans-shinjiro-koizumi-confronts-critics-coal/\#.XlFWrC16OWg.

Kagan Robert. 2004. "America's Crisis of Legitimacy". "Foreign Affairs" 2: 65-87. Kagan Rrobert. 2003. Of Paradise and Power. America and Europe in the New World Order. New York: Alfred A. Knopf.

Keohane Robert. 2002. "Rational Choice and International Law". "Journal of Legal Studies" 1: 307-319.

Khanna Parag. "The End of the Nation-State". "The New York Times". 14.10.2013. https://www.nytimes.com/2013/10/13/opinion/sunday/theend-of-the-nation-state.html.

Khurana Gurpeet S. 2007. "Security of Sea Lines: Prospects for India-Japan Cooperation". "Strategic Analysis" 1: 139-153.

Kirchner Emil J., Dorussen Han. 2019. EU-Japan Security Cooperations. Trends and Prospects, London-New York: Routledge. 
Kuźnar Andżelika, Menkes Jerzy. 2018. „Indo-Azja-Pacyfik - instytucjonalizacja współpracy”. In: Handel i finanse międzynarodowe w świetle wyzwań XXI wieku, ed. Małgorzata Bartosik-Purgat, Alicja Hadryś-Nowak 63-74. Warszawa CeDeWu.

Layne Christopher. 1994. "Kant or Cant. The Myth of the Democratic Peace". "International Security" 2: 5-49.

Lehmann Jean-Pierre, Engammare Valérie. "Beyond Economic Integration: European Lessons for Asia Pacific?”. "The Globalist”, 03.02.2014. https:// www.theglobalist.com/beyond-economic-integration-european-lessons-asia-pacificl.

Lieberthal Kenneth. "The American Pivot to Asia". "Foreign Policy", December 21, 2011: https://foreignpolicy.com/2011/12/21/the-american-pivot-to-asia/.

Mansfield Edward D., Milner Helen V. 1999. “The New Wave of Regionalism”. "International Organizations" 3: 589-627.

Mansfield Edward D., Solingen Etel. 2010. "Regionalism”. "Annual Review of Political Science"13: 145-163.

MedcalfRory. "The Indo-Pacific. What's in a Name? Brookings". October 2013. https:// www.brookings.edu/articles/the-indo-pacific-whats-in-a-name/.

Menkes Jerzy, Wasilkowski Andrzej. 2017. Organizacje międzynarodowe. Prawo instytucjonalne. Warszawa: PWN.

Armitage, Richard L., Nye Joseph S. Jr. February 2007. "The U.S.-Japan Alliance. Getting Asia Right through 2020", CSIS.

Nye Joseph S. Jr. "Amerikas Macht". In: Empire Amerika - Perspektiveneinerneuen Weltordnung, ed. Ulrich Speck, Natan Sznaider, 156-172. Stuttgart: Deutsche Verlags-Anstalt.

Przeździecka Eliza, Górska Rumiana, Kuźnar Andżelika, Menkes Jerzy. 2019. The effects of EU-Japan economic partnership agreement for Poland's economy, "Ekonomista" 6, 701-733.

Riyanto Yohanes E., Hur Jung. "On the Explanation of Regionalism Waves". December 22, 2019 https://pdfs.semanticscholar.org/e9d8/413ff16d0db90bdda4bda7e07a5ab8ed49f5.pdf.

Sanger David E., Haberman Maggie. "Donald Trump sets conditions for defending NATO Allies against attack". "New York Times". 20.07.2016. https:// www.nytimes.com/2016/07/21/us/politics/donald-trump-issues.html.

Singh Shailja. 2014. WTO Plus Commitments in RTAs, Centre for WTO Studies, New Delhi http://wtocentre.iift.ac.in/CBP/WTO\%20Plus\%20Commitments_Shailja.pdf. 
Siriwardana Mahinda, Yang Jinmei. 2008. "GTAP Model Analysis of the Economic Effects of an Australia-China FTA: Welfare and Sectoral Aspects". "Global Economic Review" 3: 341-362.

Sunesen Eva R., Francois Joseph F., Thelle Martin H. 2010. Assessment of barriers to trade and investment between the EU and Japan. Final report. Copenhagen Economics.

Suzuki Hitoshi. 2017. The new politics of trade: EU-Japan. "Journal of European Integration”, 39 (7). 875-889. http://eprints.lse.ac.uk/87318/1/Suzuki_ New\%20Politics\%20of\%20Trade\%20EU-Japan.pdf.

Suzuki Kazuto. "Perspectives on an Uncertain World: Japan-EU Views on the United States and Russia". Instituto Affari Internazionali. Commentaries, 18, 21.03.2018. https://www.iai.it/en/pubblicazioni/perspectives-uncertainworld-japan-eu-views-united-states-and-russia.

Taniguchi Tomohiko. 2010. "Beyond "The Arc of Freedom and Prosperity": Debating Universal Values in Japanese Grand Strategy, The German Marshall Fund of the United States". "Asia Paper Series" October: 1-5, http://www. gmfus.org/publications/beyond-arc-freedom-and-prosperity-debating-universal-values-japanese-grand-strategy.

Tongzon Jose L. 2001. "China's Membership in the World Trade Organization (WTO) and the Exports of the Developing Economies of East Asia: A Computable General Equilibrium Approach". "Applied Economics" 15: 1943-1959.

Viray Patricia Lourdes. "US: We will not ignore China's challenge to rules-based order". "The Philippine Star". 19.10.2017, http://www.philstar.com/headlines/2017/10/19/1750399/us-we-will-not-ignore-chinas-challenge-rulesbased-order.

Volcovici Valerie. "At climate talks, Japan's Koizumi confronts critics over coal". "Reuters", December 9, 2019, https://www.reuters.com/article/us-climatechange-accord-japan/at-climate-talks-japans-koizumi-confronts-critics-overcoal -idUSKBN1YF2KG.

Wallerstein Immanuel. 2006. "The Curve of American Power". "New Left Review” 40 http://www.iwallerstein.com/wp-content/uploads/docs/NLRCURVE.PDF.

Waltz Kenneth N. 2000. Structural Realism after the Cold War. "International Security 1: 5-41. http://www.columbia.edu/itc/sipa/U6800/readings-sm/ Waltz_Structural\%20Realism.pdf.

Webster Charles K. 2015. British Diplomacy 1813-1815. Selected Documents Dealing with the Reconciliation of Europe, Sagwan Press. 
